Article

\title{
Environmental Design Guidelines for Circular Building Components: The Case of the Circular Building Structure
}

\author{
Leonora Charlotte Malabi Eberhardt ${ }^{1, *}$, Anne van Stijn ${ }^{2}$, Liv Kristensen Stranddorf ${ }^{3} \mathbb{D}$, Morten Birkved ${ }^{4} \mathbb{D}$ and \\ Harpa Birgisdottir ${ }^{1}$ (D)
}

1 Department of the Built Environment, Aalborg University, 2450 Copenhagen, Denmark; hbi@build.aau.dk

2 Department of Management in the Built Environment, Faculty of Architecture and the Built Environment, Delft University of Technology, 2628 BL Delft, The Netherlands; a.vanstijn@tudelft.nl

3 Department of Civil Engineering, Technical University of Denmark, 2800 Kgs. Lyngby, Denmark; livks@msn.com

4 SDU Life Cycle Engineering, Department of Chemical Engineering, Biotechnology and Environmental Technology, University of Southern Denmark, 5230 Odense-M, Denmark; morb@kbm.sdu.dk

* Correspondence: lcl@build.aau.dk

check for updates

Citation: Malabi Eberhardt, L.C.; van Stijn, A.; Kristensen Stranddorf, L.; Birkved, M.; Birgisdottir, $\mathrm{H}$.

Environmental Design Guidelines for Circular Building Components: The Case of the Circular Building Structure. Sustainability 2021, 13, 5621. https://doi.org/10.3390/su13105621

Academic Editor:

Abdollah Shafieezadeh

Received: 31 March 2021

Accepted: 5 May 2021

Published: 18 May 2021

Publisher's Note: MDPI stays neutral with regard to jurisdictional claims in published maps and institutional affiliations.

Copyright: (c) 2021 by the authors. Licensee MDPI, Basel, Switzerland. This article is an open access article distributed under the terms and conditions of the Creative Commons Attribution (CC BY) license (https:/ / creativecommons.org/licenses/by/ $4.0 /)$.

\begin{abstract}
Transitioning to a circular built environment can reduce the environmental impacts, resource consumption and waste generation emanating from buildings. However, there are many options to design circular building components, and limited knowledge on which options lead to the best environmental performance. Few guidelines exist and they build on conventional environmental performance assessments that focus on single life cycles, whereas the circular economy (CE) focuses on a sequence of multiple use- and life cycles. In this article, environmental design guidelines for circular building components were developed in five steps. First, examples of circular variants of a building structure were synthesized. Second, the environmental performance of these variants was compared with a business-as-usual variant through Life Cycle Assessments (LCA) and Material Flow Analysis (MFA) respectively. Circular parameters of these variants were tested using a scenario-specific approach. Third, from 24 LCAs and MFAs, a scorecard, rules-of-thumb and nine environmental design guidelines for designing circular building components were developed that provide guidance on which circular pathways and variants lead to the best environmental performance. For components with a long functional-technical lifespan, the following are promoted: resource efficiency, longer use through adaptable design, low-impact biomaterials and facilitating multiple cycles after and of use. Fourth, the design guidelines were evaluated by 49 experts from academia, industry and government in seven expert sessions. Further research is needed to validate the generalizability of the design guidelines. However, this research makes an important step in supporting the development of circular building components and, subsequently, the transition to a circular built environment.
\end{abstract}

Keywords: circular economy (CE); life cycle assessment (LCA); material flow analysis (MFA) design guidelines; buildings; structure

\section{Introduction}

The global building sector is responsible for approximately 39\% of all human-induced emissions of which $11 \%$ comes from manufacturing building materials and products [1]. Construction and maintenance of buildings and infrastructure represent almost $50 \%$ of the global material consumption [2] and in return generates $40 \%$ of solid waste streams in developed countries [3]. Around 10-15\% of building materials are wasted during construction and $54 \%$ of demolition materials are landfilled due to destructive demolition or toxicity. At the same time, the building sector is experiencing a scarcity of resources. Zinc and chromium, used in roofing, facades, technical building services, etc., are predicted to reach their supply horizon within the next 20 years [4]. While the demand for gypsum 
is increasing, the production of industrial gypsum has been reduced, due to reduced coal incineration (e.g., in Denmark [5]). The demand for sand used in concrete is growing faster than natural sources can sustain [6]. In parallel, construction raw material prices are increasingly volatile and rising [7,8]. For example, between 2014 and 2018 cement and construction metals prices by $9.4 \%$ and $7.2 \%$ respectively in the United Kingdom increased [9]. These issues are especially concerning when considering that the global building stock is expected to double in 2050 [1]. A radically different approach is needed for the buildings to be built in the next 30 years.

The concept of Circular Economy (CE) can facilitate minimizing these unresolved issues in the building sector. This is done by optimizing current and future resource loops by narrowing (efficient resource use), slowing (temporally extended use) and closing (cycling) resource loops $[10,11]$. CE is operationalized through value retention processes (VRPs) (also known as R-imperatives) such as reduce, reuse, repair, refurbish, recycle and recover that seek to keep materials at their highest utility and value for as long as possible [12]. VRPs can be aided by a multitude of different design strategies (e.g., design for disassembly, adaptability). Some VRPs result in re-loops (e.g., when a component or material is reused or recycled) [13]. CE does not only consider one re-loop but a sequence of multiple re-loops also called cascading systems (e.g., when a component or material is used in a series of different applications one after the other) [14]. The built environment can gradually become (more) circular by integrating circular principles into existing or new building components. However, this will require fundamental changes in building activities, supply chains and market structures within the building sector.

There is no commonly accepted definition of CE in the building sector [15] and the concept embraces a variety of different design strategies $[13,16,17]$. Thus, there are many options to design circular building components $[18,19]$. Consequently, circular building component designs may incorporate and combine different attributes of the $\mathrm{CE}$ concept for which the potential for circularity is very different (e.g., using bio-based, recyclable and/or reusable materials that can be returned to biological or technical material flows, life extension through durable and/or adaptable design). There are many guidelines on how to implement CE in buildings [20-25]. However, questions remain on which circular design options result in the optimum environmental and resource performance to support design and decision making.

Two methods are often applied for environmental performance assessment; Life Cycle Assessment (LCA) is a scientifically based and ISO-standardized method for assessing the environmental performance of a given product, service or system over its entire life cycle/value chain, i.e., from raw material extraction, production, use to end-of-life (i.e., cradle to grave) [26-29]; Material Flow Analysis (MFA) is used to characterize material flows and more recently stocks [30,31] and can be used in parallel with/to support LCA. Both are commonly accepted methods to quantify and even certify a building's environmental performance [26] and resource consumption [30] and can facilitate CE decision-making [32].

Environmental building design guidelines exist $[18,33,34]$. These can be categorized into two main types: generative and evaluative, based on their applicability at the frontor back-end of the product development process [35]. "Generative" refers to front-end support to generate designs (e.g., guidelines, criteria, rules-of-thumb, case examples) while "evaluative" offers support to evaluate designs at the end of design (e.g., using LCA and MFA). LCA has the most prominent potential to reduce building life cycle environmental impacts when applied at the front-end in the early design stage [36-38]. However, industry practitioners view LCA as being too laborious and time-consuming $[39,40]$. Thus, simplifications are needed to encourage the use of LCA knowledge in practical design (e.g., guidelines based on LCA [34,41-43]). However, existing LCA guidelines are challenging to use for designing "ideal" circular solutions for several reasons: (1) they predominantly focus on conventional building design [43], (2) they build on conventional environmental performance assessment methods that focus on assessing single life cycles, (3) they focus on the overcomplex building level or the limiting material level to reach sustainability 
goals, (4) they tend to focus on single circular design strategies and (5) they tend to build on single impact indicators (e.g., embodied greenhouse gas emissions [18,34]), neglecting other impacts of environmental importance. Although, some environmental design guidelines exist for the building component level $[44,45]$ guidelines that specifically target the design of circular building components with multiple use- and life cycles are needed in practice.

In this article, the environmental and resource benefits of existing CE design options are quantified to derive environmental design guidelines for circular building components on the most optimal CE design options and combinations of design options using LCA and MFA based on the case of a building structure. This paper was part of a larger collaborative research project between Danish and Dutch researchers, housing companies and industry partners that included the development of a CE LCA method and exemplary circular kitchens, façades and structures [46-48].

\section{Methods}

The study at hand explores the environmental performance of various and significantly different circular visions based on theoretical design models and assumptions of "ideal" conceptual design variants deviating from the current practice. By applying an iterative research-through-design method, design guidelines for circular building components were developed in five steps. In step 1, design variants for a circular building structure were synthesized. Due to the large share of the total building mass, the structure can contribute significantly to the environmental impact of a building. In step 2, the environmental performance of the design variants was compared with a business-as-usual variant using LCA and MFA. A scenario-specific sensitivity analysis of circular parameters was performed as part of the interpretation of the LCA and MFA to validate the results and guide the development of the design guidelines. In step 3 , the environmental design guidelines were derived from the LCA and MFA results. In step 4, the design guidelines were evaluated with LCA and CE design experts from academia, industry and government. Finally, the resulting design guidelines were discussed and opportunities for further development were identified.

\subsection{Design Variants for the Circular Structure}

This study was initially targeted at the Danish building context that is dominated by concrete structures. Compared to other building components, concrete structures are more challenging from a CE perspective as they are environmentally intensive to produce, are not easily reusable with current construction methods and therefore down-cycled and are often prematurely demolished. Thus, different circular design variants of a structure were developed on a concept level in co-creation with TU Delft, AMS Institute, Aalborg University, the Danish contractor MT Højgaard and other industry partners. The structural variants were generated by combining various circular design options identified by van Stijn and Gruis [49], environmental optimization opportunities found from [50,51] and precedent and current circular building projects [12,52,53] and products [54]. A tunnel structure ( $3 \mathrm{~m}$ high, $6 \mathrm{~m}$ wide and $7.2 \mathrm{~m}$ deep) for multi-storey ( +3 storey) buildings was used. Only the "raw" structure was considered; additional finishing was neglected. In terms of circular designs for structures, the Danish building sector is mostly focused on lighter concrete structures, substituting concrete with bio-materials, reuse of concrete elements through design for disassembly and extending the use through easy adaptations. On that basis, four variants were considered plausible future scenarios and representative of "pure" and fundamentally different circular pathways (facilitating different re-loops), see Figure 1. The floor and wall thicknesses of the variants were assumed based on supplier information, example details and dimensioning rules-of-thumb. The design variants were designed as a composite of components, parts and materials which—potentially—have different and multiple use-, and life cycles (see variant flow diagrams in Supplementary Materials Figure S1). 


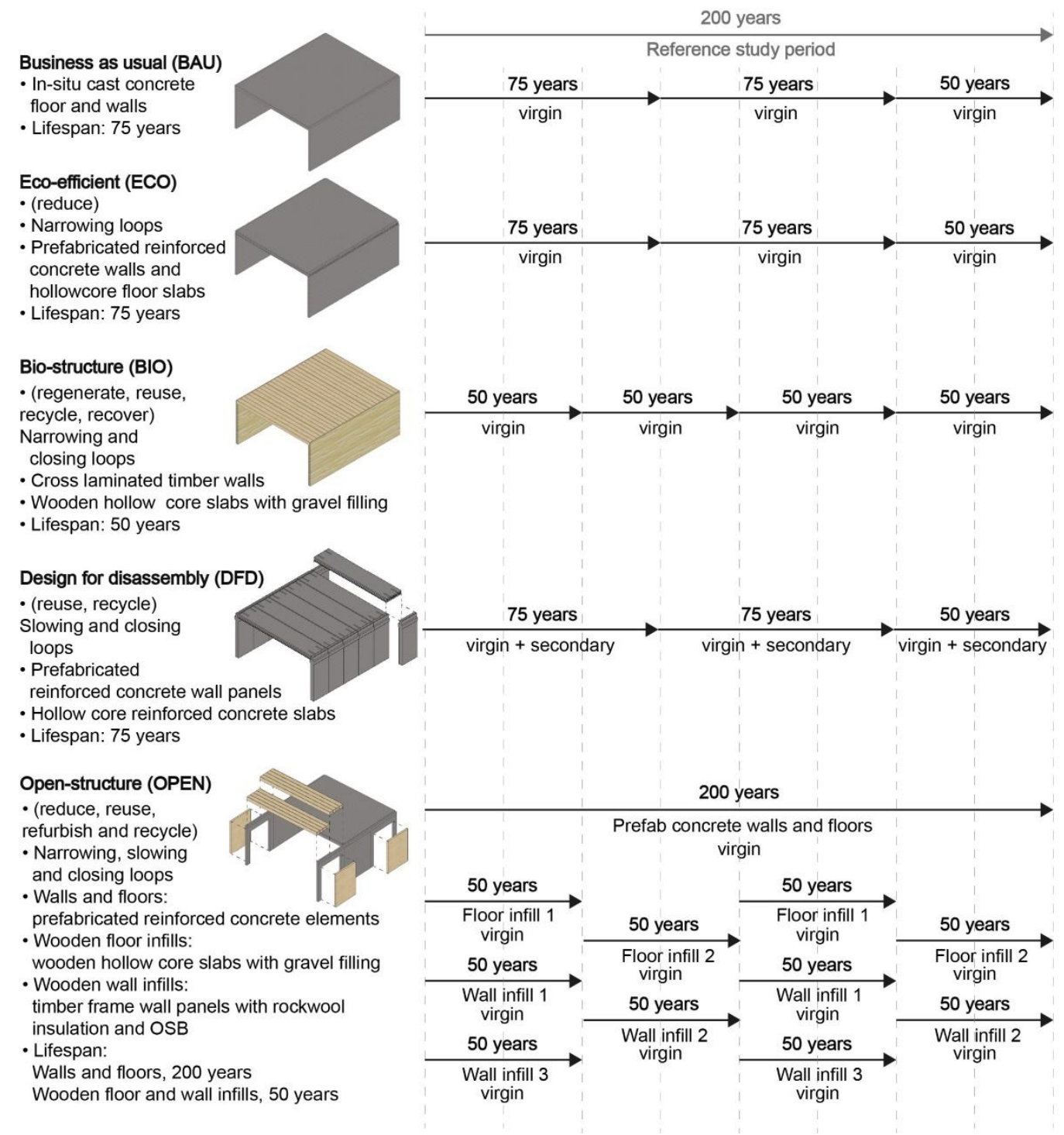

Figure 1. The circular principles of the structural design variants and their functional lifespan compared to the reference study period of 200 years.

The "business-as-usual" (BAU) structure, represents the current practice; consisting of in-situ casted reinforced concrete. A 75-year functional lifespan was assumed. At the end-of-life (EoL) the structure is demolished, and $90 \%$ of the concrete is crushed for road filling and $10 \%$ goes to landfill, whereas $99 \%$ of the reinforcement steel is recycled into new steel products and $1 \%$ is landfilled [55].

Concrete structures are often over-dimensioned, with unnecessarily large amounts of concrete and reinforcement steel [56]. The "eco-efficiency" (ECO) structure, narrows loops, saving $22 \%$ and $25 \%$ of the concrete and reinforcement steel respectively on the BAU through lean design using prefabricated elements that are cast together on site. The BAU's functional lifespan and EOL are assumed for the ECO.

The "bio" (BIO) structure, narrows and closes loops using wood: a renewable, low impact, biomaterial. It consists of prefabricated cross-laminated timber (CLT) walls and timber hollow core floor slabs. These are connected with dowelled joints. A 50-year technical lifespan is assumed, in accordance with the product. At EoL, the hollow-core timber floor slabs are recycled, after which they are incinerated for energy recovery. A 100 -year technical lifespan is assumed for the CLT wall elements. Hence, they can be reused once after 50 years, after which they are recycled and finally incinerated for energy recovery. 
Concrete elements are often difficult to separate without damage because they are cast together. Hence, at EoL, they are commonly crushed into concrete gravel for road filling and the reinforcement steel is recycled into new steel products. The "design for disassembly" (DFD) structure, slows and closes loops by using long-lasting materials, and standard-sized prefabricated concrete elements that are demountable for direct reuse, thereby prolonging the elements' service life and avoiding burdensome production of new concrete $[57,58]$. The DFD consists of a mix of virgin and secondary prefabricated, reinforced concrete wall elements and hollow-core reinforced concrete floor slabs with demountable steel connections. A 75-year functional lifespan of the building in which the elements are placed is assumed. However, due to the long technical lifespan of concrete and separable joints, four (re)uses of the elements (i.e., in four different locations) is assumed, after which they are recycled.

Buildings often become prematurely obsolete because of failure to predict and meet changing functional requirements over time $[59,60]$. Hence, the building industry potentially fails to exploit the long technical lifespan of concrete. The "open" (OPEN) structure, narrows, slows and closes loops by applying a leaner design than the BAU, durable materials and facilitates adaptability for future changes in use. It consists of prefabricated reinforced concrete wall and floor elements that are cast together. The OPEN structure has three and four openings in the walls and floors, respectively. Insulated timber frame wall panels and hollow-core timber floor slabs can be placed or removed within these openings to combine or separate adjacent floors and rooms if needed, prolonging the functional lifespan to 200 years with changes in the infill panels every 50 years. Both the concrete structure and infill panels are recycled at EoL.

The numbers of use- and life cycles, functional and technical lifespans of components and materials were estimated based on the Danish standard lifespans for building LCAs stated by Aagaard, Brandt, Aggerholm and Hauhbølle [61] and supplier information. The functional lifespan of the DFD (four uses in different locations) and OPEN structure (200 years) deviate from the standard lifespan (120 years) for concrete stated by Aagaard, Brandt, Aggerholm and Hauhbølle [61]. There are many examples of the technical lifespan of concrete being much longer than 120 years. Therefore, the DFD and OPEN structure explores the possibilities of utilising the long technical lifespan of concrete through lifeextension design solutions to achieve a longer functional lifespan. The DFD and OPEN structure build on Habraken's [62] "open" building movement and Stewart Brand's [63] design theory on "shearing layers", assuming a functional lifespan of up to 300 years when the structure becomes independent from the rest of the building layers. In light of the resource and climate challenge, it is imaginable that society will be forced to maintain buildings for longer in the future than is the current practice. Under these circumstances, it is valid to assume that contemporary buildings will last 200 years. Hence, it is necessary to compare long-lasting designs with multiple reference scenarios, taking various future developments into consideration. In this case, a traditional lifespan is not sufficient for measuring the potential benefit of circular structures such as the DFD and OPEN structure.

The material composition of the variants is shown in Supplementary Materials Figure S2.

\subsection{Method for the Life Cycle Assessment}

In this study, the focus of assessment is on the environmental impact of each structure within a system of cycles. Thus, all the use-, and life cycles of components, parts and materials inside, and outside of the assessed system (see the flow diagrams in Supplementary Materials Figure S1), were inventoried following the method described by van Stijn, Eberhardt, Wouterszoon and Meijer [47]. For example, for the "DFD" structure, the production, use, reuse(s), recycling and disposal of components in subsequent use-cycles were included. However, processes such as assembly, drilling, and cutting, related to the variants were not included. Capital goods were excluded in the foreground system. 
The EN15978 building standard was followed. However, the CE LD allocation approach developed by Eberhardt, van Stijn, Nygaard Rasmussen, Birkved, and Birgisdottir [46], which is more closely aligned with the multi-cycling aspect of CE, was used to assess and divide impacts over multiple use- and life cycles. This approach has been shown to create incentives for short-term and long-term narrowing, slowing and closing of loops in line with the CE concept [46]. Impacts from virgin material production and disposal are allocated in a linearly degressive way to all use cycles, with the highest share of impacts being allocated to the cycle where the impact is induced. The re-loop impacts of a material (i.e., reuse and recycling) are equally allocated between the use cycle(s) that share the material or component. The approach qualitatively assumes a limited number of cycles for materials, such as metals, that are open-loop recycled for an unknown number of times. The approach does not consider the length of the cycles. For that reason, all cycles are considered to have the same length, including recycling and energy recovery cycles.

The functional unit was the use of a specific circular tunnel structure with the dimensions of $3 \mathrm{~m}$ high, $6 \mathrm{~m}$ wide and $7.2 \mathrm{~m}$ deep for multi-storey ( +3 story) buildings for a period of 200 years, in a circular system. The reference study period was set according to the variant with the longest lifespan (i.e., 200 years) to be able to compare the variants to one another (see Figure 1). Hence, the BAU, ECO and DFD (with a functional lifespan of 75 years) were placed 2.67 times within the 200 -year reference study period. In other words, only a 0.67 fraction of the impacts of the third placement of the structure was counted, as the third structure would reach EoL prematurely.

The modelling was carried out in openLCA v1.9.0 software (GreenDelta, Berlin, Germany), using Centre for Environmental Studies (CML) CML-IA baseline characterization factors from which a set of 11 environmental, resource-depletion and toxicology midpoint impact categories were assessed (global warming potential (GWP), ozone depletion potential (ODP), photochemical ozone creation potential (POCP), acidification potential (AP), eutrophication potential (EP), abiotic depletion potential for elements (ADPe), abiotic depletion potential for fossil resources (ADPf), freshwater aquatic ecotoxicity potential (FAETP), marine aquatic ecotoxicity potential (MAETP), human toxicity potential (HTP) and terrestrial ecotoxicity potential (TETP)). CML is commonly used by the building sector, for example in the Deutches Gesellschaft für Nachhaltiges Bauen (DGNB) certification system. The Life Cycle Inventory (LCI) of the background system was based on the Ecoinvent 3.4 APOS database [64], using system processes to get aggregated results. APOS already uses an allocation principle in the background system. However, APOS is the best option for controlling the allocation approach in the foreground system. Furthermore, biogenic carbon (e.g., in wood) is excluded in openLCA v1.9.0. The design variants' LCI was modularly structured, separating components, parts and materials based on material, lifespan and life cycle(s). Qualified estimations were made together with the partners on transport distances ( $480 \mathrm{~km}$ the longest transport distance in Denmark), production, disposal, number of use- and life cycles, lifespans of components, parts and materials based on supplier information and amount of materials. Assumptions were kept coherent between variants (e.g., similar transportation distances and open-loop recycling scenarios).

\subsection{Method for the Material Flow Analysis}

The MFA was aligned with the goal and scope applied in the LCA. The material flows (direct import and export [kg]) of the variants were analyzed using the LCI developed for the LCA. The material import distinguished between virgin, non-virgin, renewable and non-renewable input. The material export distinguished between reusable, recyclable, recoverable/biodegradable and disposed materials. The material consumption of the system was calculated by subtracting reusable and recyclable material from the import. As MFA is based on the law of matter conservation, only the primary use cycle in the structure over the 200-year reference study period was calculated (see the punctured line on the flow diagrams in Supplementary Materials Figure S1). 


\subsection{Method for the Sensitivity Analysis}

The functional lifespan and future cycles are highly uncertain and difficult to predict $[46,48]$. However, they are of great importance for the design variants' performance. Furthermore, the long 200-year reference study period could result in a skewed and perhaps unfair comparison of the design variants and biased conclusions. Therefore, the influence of assumptions on lifespan and number of cycles was tested on the LCA (focusing on global warming potential (GWP)) and MFA results. A number of "what-if" scenarios that encompassed a "better" or "worse" case compared to the base scenario were analyzed (see Table 1). The scenarios considered how a variant's performance would change: (1) if the length of the variant's use were shorter/longer than designed for, (2) if the length of the variant's material cycles were longer/shorter than designed for, (3) if reuse/recycling cycles that the variant had been designed for were not realized in the future and (4) if more cycles than the variant were designed for occurred in the future. The sensitivity of lifespans was tested in two ways. For the first test, the length of the use of the structure was varied within the 200-year reference study period (i.e., varying the functional and technical lifespans in parallel). There was no change in the amount or length of material cycles and therefore the allocation fractions from the baseline scenario stayed the same. The performance of the BAU, ECO and BIO was tested assuming they were used for a shorter (25 years (L25)) and a longer (200 years (L200)) period. The performance of the OPEN structure was tested assuming that the concrete structure was kept for 200 years with increased or decreased adaptations placing and removing the infill modules every 25 years (L200_25) and 75 years (L200_75). Furthermore, it was examined how the OPEN structure would perform if it prematurely reached its EoL after 75 years, aligning it with the BAU, ECO and DFD (L75_50) and including the effect of an increased number of adaptations (every 25 years (L75_25)) within the 75 years. For the second test, the lifespan of the materials was maintained based on the baseline scenario of the variants but varying the length of the material cycles within the material lifespan. Thus, the number, as well as types of cycles, change, leading to a change in the allocation fraction. For example, it is uncertain when and how many times reuse will occur. Hence, for the DFD, the effects of keeping the material lifespan based on the baseline scenario but varying the length of the material cycles with 25 and 200 years within that lifespan were tested. All structural variants were tested for adding an additional cycle $(C+1)$ (i.e., local reuse with no additional transport or processes) by changing the allocation fractions. Furthermore, the DFD was tested assuming one $(\mathrm{C}-1)$ or two $(\mathrm{C}-2)$ reuse cycles were not realized. The most uncertain cycles were removed first, namely the cycles at the furthest end of the chain of cycles. However, current final recycling, incineration and waste disposal practices were maintained.

Table 1. Sensitivity scenarios tested for each of the structural design variants.

\begin{tabular}{|c|c|c|c|c|c|c|c|}
\hline \multicolumn{2}{|c|}{ Sensitivity Scenarios } & Abbreviation & BAU & ECO & BIO & DFD & OPEN \\
\hline \multirow{3}{*}{$\begin{array}{c}\text { Number of } \\
\text { cycles }\end{array}$} & -2 cycles & $\mathrm{C}-2$ & & & & $x$ & \\
\hline & -1 cycle & C-1 & & & & $x$ & \\
\hline & +1 cycle & $C+1$ & $x$ & $x$ & $x$ & $x$ & $x$ \\
\hline \multirow{6}{*}{ Lifespan } & 25 years & L25 & $x^{1}$ & $x^{1}$ & $x^{1}$ & $x^{2}$ & \\
\hline & \multirow{2}{*}{75 years } & L75_50 & & & & & $x^{1}$ \\
\hline & & L75_25 & & & & & $x^{1}$ \\
\hline & \multirow{3}{*}{200 years } & L200 & $x^{1}$ & $x^{1}$ & $x^{1}$ & $x^{2}$ & \\
\hline & & L200_25 & & & & & $x^{1}$ \\
\hline & & L200_75 & & & & & $x^{1}$ \\
\hline
\end{tabular}

Note: Type of lifespan sensitivity analysis applied: $\left({ }^{1}\right)$ varying the length of the use of the structure and $\left(^{2}\right.$ keeping the lifespan of the materials based on the baseline scenario of the variant but varying the length of the material cycles within the material lifespan. 


\subsection{Method for Developing Design Guidelines}

Comparing the overall performance of one variant with another was challenging due to burden-shifting: the environmental performance of the design variants varies from one environmental impact and material flow category to the other. Hence, deriving design guidelines required an evaluation methodology to determine the relative importance of different impact and material flow categories in the LCA and MFA respectively. Various suggestions for ranking environmental optimization strategies to support decision-making exist and can commonly be categorized as: (1) normalization and/or weighting [65], (2) ranking based on single-issues (e.g., based on embodied greenhouse gas emission) [65], (3) ranking on damage-based single indicators e.g., "eco-indicator-99" [65], or (4) ranking on prevention-based indicators "shadow cost" [66], or "eco-cost" [67]. There are (dis)advantages of each method, the different methods yield different results and there is no consensus on which method to use.

In this study, the variants and different scenarios were ranked according to the percentage savings of their normalized LCA results, and MFA results compared to the BAU. Each impact category of the LCA was given equal weight to calculate an average percentage saving of each variant across all 11 environmental impact categories compared to the BAU. This procedure was repeated for the material flow types of the MFA. For the MFA, the percentage savings of five material flow categories were considered: (1) total material import, (2) percentage of virgin import, (3) non-renewable import (4) biodegraded, recovered, or discarded material export, and (5) final material consumption. Then, each variant was ranked using two methods to create transparency of the difference between using different decision-making methods: (1) ranking based on an average percentage saving of the LCA (i.e., all impacts) and MFA based on equal weighting, and (2) ranking based on an average percentage saving of the GWP (i.e., single-issue method) and MFA based on an equal weighting. Design guidelines were developed in three different formats that are usable by the designer in the early design stage. First, from the ranking, a scorecard was developed for all the assessed variants and scenarios. In the scorecards, the circular design options applied in the technical, industrial and business models were also listed. Second, rules-of-thumb on circular design principles were developed by comparing savings of selected design scenarios with "pure" circular principles (e.g., adding/subtracting cycles, substituting materials or extending/reducing the lifespan) towards each other. Third, nine rules for designing circular building components were induced by identifying "lessons learned" from comparing the LCA and MFA results of the examples of circular structures, as well as the circular kitchens and facades of which this paper is a collaborative part of. Hence, rules 1-5 and 7 are similar to those of the kitchens and facades whereas rules 6,8 and 9 are slightly different for the structure.

\subsection{Method for Expert Sessions}

Seven semi-structured expert sessions were conducted with 49 experts within the fields of LCA, CE design and CE built environment from academia, industry and government. The LCA and MFA method and results, as well as the derived and induced design guidelines, were presented to the experts. They were asked to answer two questions: (1) do you think the design guidelines are valid? and (2) how would you improve them? Following these questions, there was time for discussion. Answers and remarks were summarized, categorized and analyzed from the session transcripts using an inductive coding technique (i.e., emergent coding) to quantify the content (see Supplementary Materials Table S1) $[16,68,69]$. The expert sessions were used to iteratively improve the design guidelines. Hence, the majority of the improvements suggested during the expert sessions are implemented into the design guidelines presented in the paper at hand. Any remaining recommendations are included in the discussion section. 


\section{Results}

\subsection{Results of the Life Cycle Assessment and Material Flow Analysis}

Table 2 summarizes the LCA and MFA results. Additionally, Supplementary Materials Figure S3 shows a graphical representation of the results of the MFA from Table 2. Table 2 shows that all of the variants result in material import reductions from $18-69 \%$ and a notable impact reduction in GWP from $24-84 \%$ compared to the BAU. However, only the ECO and OPEN realize impact reductions in all 11 environmental impact categories compared to the BAU. The ECO results in impact saving ranging from $23-41 \%$ compared to the BAU. However, the ECO has, as the only variant, a material consumption due to material disposal following the current practice. The other variants save $100 \%$ material consumption compared to the BAU since all the materials go to either reuse or recycling. Of all the variants, the OPEN structure exhibits the best performance in all 11 environmental impact categories with high percentage savings ranging from $64-84 \%$ compared to the BAU. In addition, the OPEN structure significantly reduces the material import by $69 \%$ compared to the BAU. Due to noteworthy transportation impacts related to the reuse of the heavy prefabricated concrete elements, the DFD exhibits a higher impact in ODP, ADPe, ADPf and HTP $(-46 \%,-34 \%,-14 \%$ and $-15 \%$ respectively). However, the DFD saves $69 \%$ virgin material by partially using secondary materials. The BIO variant has a higher impact in the categories ODP, POCP, EP and ADPe $(-22 \%,-44 \%,-17 \%$ and $-30 \%$ respectively) due to the forestry harvesting related to the cross-laminated timber. Thus, the substitution of materials, e.g., biomaterials (BIO) does not necessarily lead to a better environmental performance in all environmental impact categories. On the other hand, the BIO structure significantly reduces the material import by $64 \%$ and uses $100 \%$ renewable material compared to the BAU. Thus, changing the design and materials of the BAU results in a shift of the burden to other impact categories and material flows and does not always lead to savings. For all the variants, the environmental impact primarily originates from material production and material processes.

Figure 2 informs on the variants temporal impact performance over the 200-year reference study period showing tipping points between the variants depending on their lifespan (T) based on GWP. The BIO, DFD and OPEN have quite similar emissions in year 1 but very different emissions 200 years into the future. When $\mathrm{T}<50$ years, the BIO variant has the lowest GWP compared to the other variants. However, the BIO variant's GWP benefits are offset over time because it is replaced more frequently than the other variants due to its shorter technical lifespan of 50 years thereby gradually increasing the GWP. When $\mathrm{T}>50$ years, the OPEN and DFD structure perform better than the BIO variant. When $\mathrm{T}>75$ years, the OPEN structure has the lowest GWP followed by the BIO structure. At $\mathrm{T}=200$ the OPEN structure has a much lower GWP than the other variants as the primary concrete structure of the OPEN variant is kept for 200 years, and only the infill modules are placed or removed every 50 years due to adaptations. Hence, the benefits of the variants are dependent on the timeframe. Therefore, it is important to not only consider the present burdensome production but also temporal aspects such as future cycles. 
Table 2. Environmental impacts and material flows of each structural variant.

\begin{tabular}{|c|c|c|c|c|c|c|}
\hline \multirow{2}{*}{ Impact Category } & \multirow{2}{*}{ Unit } & \multicolumn{5}{|c|}{ Design Variants } \\
\hline & & BAU & ECO & BIO & DFD & OPEN \\
\hline GWP & $\mathrm{kg} \mathrm{CO} 2$ eq. & $1.32 \times 10^{4}$ & $\begin{array}{c}1.01 \times 10^{4} \\
(24 \%)\end{array}$ & $\begin{array}{c}5.69 \times 10^{3} \\
(57 \%)\end{array}$ & $\begin{array}{c}8.08 \times 10^{3} \\
(39 \%)\end{array}$ & $\begin{array}{c}2.15 \times 10^{3} \\
(84 \%)\end{array}$ \\
\hline ODP & kg CFC-11 eq. & $6.50 \times 10^{-4}$ & $\begin{array}{c}4.50 \times 10^{-4} \\
(31 \%)\end{array}$ & $\begin{array}{c}7.90 \times 10^{-4} \\
(-22 \%)\end{array}$ & $\begin{array}{c}9.5 \times 10^{-4} \\
(-46 \%)\end{array}$ & $\begin{array}{c}1.60 \times 10^{-4} \\
(75 \%)\end{array}$ \\
\hline POCP & $\mathrm{kg} \mathrm{C}_{2} \mathrm{H}_{4}$ eq. & 1.36 & $\begin{array}{c}9.98 \times 10^{-1} \\
(27 \%)\end{array}$ & $\begin{array}{c}1.97 \\
(-44 \%)\end{array}$ & $\begin{array}{c}1.19 \\
(12 \%)\end{array}$ & $\begin{array}{c}4.47 \times 10^{-1} \\
(65 \%)\end{array}$ \\
\hline $\mathrm{AP}$ & $\mathrm{kg} \mathrm{SO} \mathrm{S}_{2}$ eq. & $3.16 \times 10$ & $\begin{array}{c}2.32 \times 10 \\
(27 \%)\end{array}$ & $\begin{array}{c}3.08 \times 10 \\
(3 \%)\end{array}$ & $\begin{array}{c}2.34 \times 10 \\
(26 \%)\end{array}$ & $\begin{array}{c}7.81 \\
(64 \%)\end{array}$ \\
\hline $\mathrm{EP}$ & $\mathrm{kg} \mathrm{PO}_{4}{ }^{3-}$ eq. & $1.05 \times 10$ & $\begin{array}{c}7.77 \\
(26 \%)\end{array}$ & $\begin{array}{c}1.23 \times 10 \\
(-17 \%)\end{array}$ & $\begin{array}{c}7.00 \\
(33 \%)\end{array}$ & $\begin{array}{c}2.78 \\
(74 \%)\end{array}$ \\
\hline ADPe & kg Sb eq. & $1.38 \times 10^{-2}$ & $\begin{array}{c}1.02 \times 10^{-2} \\
(26 \%)\end{array}$ & $\begin{array}{c}1.79 \times 10^{-2} \\
(-30 \%)\end{array}$ & $\begin{array}{c}1.85 \times 10^{-2} \\
(-34 \%)\end{array}$ & $\begin{array}{c}4.21 \times 10^{-3} \\
(69 \%)\end{array}$ \\
\hline ADPf & MJ & $7.70 \times 10^{4}$ & $\begin{array}{c}5.52 \times 10^{4} \\
(28 \%)\end{array}$ & $\begin{array}{c}7.55 \times 10^{4} \\
(2 \%)\end{array}$ & $\begin{array}{c}8.81 \times 10^{4} \\
(-14 \%)\end{array}$ & $\begin{array}{c}1.78 \times 10^{4} \\
(77 \%)\end{array}$ \\
\hline FETP & kg 1,4-DB eq. & $2.39 \times 10^{3}$ & $\begin{array}{c}1.40 \times 10^{3} \\
(41 \%)\end{array}$ & $\begin{array}{c}1.72 \times 10^{3} \\
(28 \%)\end{array}$ & $\begin{array}{c}1.53 \times 10^{3} \\
(36 \%)\end{array}$ & $\begin{array}{c}4.68 \times 10^{2} \\
(80 \%)\end{array}$ \\
\hline HTP & kg 1,4-DB eq. & $2.96 \times 10^{3}$ & $\begin{array}{c}1.98 \times 10^{3} \\
(33 \%)\end{array}$ & $\begin{array}{c}2.68 \times 10^{3} \\
(9 \%)\end{array}$ & $\begin{array}{c}3.40 \times 10^{3} \\
(-15 \%)\end{array}$ & $\begin{array}{c}7.25 \times 10^{2} \\
(76 \%)\end{array}$ \\
\hline MAETP & kg 1,4-DB eq. & $5.45 \times 10^{6}$ & $\begin{array}{c}3.75 \times 10^{6} \\
(31 \%)\end{array}$ & $\begin{array}{c}5.05 \times 10^{6} \\
(7 \%)\end{array}$ & $\begin{array}{c}3.70 \times 10^{6} \\
(32 \%)\end{array}$ & $\begin{array}{c}1.35 \times 10^{6} \\
(75 \%)\end{array}$ \\
\hline TETP & kg 1,4-DB eq. & $8.10 \times 10$ & $\begin{array}{c}6.26 \times 10 \\
(23 \%)\end{array}$ & $\begin{array}{c}1.95 \times 10 \\
(76 \%)\end{array}$ & $\begin{array}{c}3.24 \times 10 \\
(60 \%)\end{array}$ & $\begin{array}{c}1.16 \times 10 \\
(86 \%)\end{array}$ \\
\hline $\begin{array}{l}\text { Import I Total } \\
\text { material }\end{array}$ & $\mathrm{kg}$ & $1.93 \times 10^{5}$ & $\begin{array}{c}1.51 \times 10^{5} \\
(22 \%)\end{array}$ & $\begin{array}{c}6.87 \times 10^{4} \\
(64 \%)\end{array}$ & $\begin{array}{c}1.58 \times 10^{5} \\
(18 \%)\end{array}$ & $\begin{array}{c}5.92 \times 10^{4} \\
(69 \%)\end{array}$ \\
\hline Import I Virgin & $\mathrm{kg}$ & $9.63 \times 10^{4}$ & $\begin{array}{c}7.53 \times 10^{4} \\
(22 \%)\end{array}$ & $\begin{array}{c}3.43 \times 10^{4} \\
(64 \%)\end{array}$ & $\begin{array}{c}2.97 \times 10^{4} \\
(69 \%)\end{array}$ & $\begin{array}{c}2.93 \times 10^{4} \\
(70 \%)\end{array}$ \\
\hline $\begin{array}{l}\text { Import I Non- } \\
\text { virgin }\end{array}$ & $\mathrm{kg}$ & 0.00 & $\begin{array}{l}0.00 \\
(0 \%)\end{array}$ & $\begin{array}{l}0.00 \\
(0 \%)\end{array}$ & $\begin{array}{c}4.95 \times 10^{4} \\
(100 \%)\end{array}$ & $0.00(0 \%)$ \\
\hline Import I Renewable & $\mathrm{kg}$ & 0.00 & $\begin{array}{l}0.00 \\
(0 \%)\end{array}$ & $\begin{array}{c}1.47 \times 10^{4} \\
(100 \%)\end{array}$ & $\begin{array}{l}0.00 \\
(0 \%)\end{array}$ & $\begin{array}{c}1.25 \times 10^{3} \\
(100 \%)\end{array}$ \\
\hline $\begin{array}{l}\text { Import I Non- } \\
\text { renewable }\end{array}$ & $\mathrm{kg}$ & $9.63 \times 10^{4}$ & $\begin{array}{c}7.53 \times 10^{4} \\
(22 \%)\end{array}$ & $\begin{array}{c}1.97 \times 10^{4} \\
(80 \%)\end{array}$ & $\begin{array}{c}7.92 \times 10^{4} \\
(18 \%)\end{array}$ & $\begin{array}{c}2.86 \times 10^{4} \\
(70 \%)\end{array}$ \\
\hline Export I Reusable & $\mathrm{kg}$ & 0.00 & $\begin{array}{c}0.00 \times 10 \\
(0 \%)\end{array}$ & $\begin{array}{c}8.84 \times 10^{3} \\
(100 \%)\end{array}$ & $\begin{array}{c}7.92 \times 10^{4} \\
(100 \%)\end{array}$ & $\begin{array}{l}0.00 \\
(0 \%)\end{array}$ \\
\hline Export I Recyclable & $\mathrm{kg}$ & $8.69 \times 10^{4}$ & $\begin{array}{c}6.79 \times 10^{4} \\
(22 \%)\end{array}$ & $\begin{array}{c}2.55 \times 10^{4} \\
(71 \%)\end{array}$ & $\begin{array}{c}0.00 \\
(100 \%)\end{array}$ & $\begin{array}{c}2.98 \times 10^{4} \\
(66 \%)\end{array}$ \\
\hline $\begin{array}{l}\text { Export I Recoverable/ } \\
\text { biodegradable }\end{array}$ & $\mathrm{kg}$ & 0.00 & $\begin{array}{l}0.00 \\
(0 \%)\end{array}$ & $\begin{array}{l}0.00 \\
(0 \%)\end{array}$ & $\begin{array}{l}0.00 \\
(0 \%)\end{array}$ & $\begin{array}{l}0.00 \\
(0 \%)\end{array}$ \\
\hline Export I Disposed & $\mathrm{kg}$ & $9.45 \times 10^{3}$ & $\begin{array}{c}7.40 \times 10^{3} \\
(22 \%)\end{array}$ & $\begin{array}{c}0.00 \\
(100 \%)\end{array}$ & $\begin{array}{c}0.00 \\
(100 \%)\end{array}$ & $\begin{array}{c}0.00 \\
(100 \%)\end{array}$ \\
\hline $\begin{array}{c}\text { Material } \\
\text { consumption }\end{array}$ & $\mathrm{kg}$ & $9.45 \times 10^{3}$ & $\begin{array}{c}7.40 \times 10^{3} \\
(22 \%)\end{array}$ & $\begin{array}{c}0.00 \\
(100 \%)\end{array}$ & $\begin{array}{c}0.00 \\
(100 \%)\end{array}$ & $\begin{array}{c}0.00 \\
(100 \%)\end{array}$ \\
\hline
\end{tabular}

Note: The colour shows a 5-level gradient between the worst (dark grey) and best (white) value. The best value is the lowest value in all indicators, except in the renewable, non-virgin, re-usable, recyclable and recoverable/biodegradable material export, where the highest value is the best. Percentage saved or added compared to the BAU is shown below each value in brackets. 


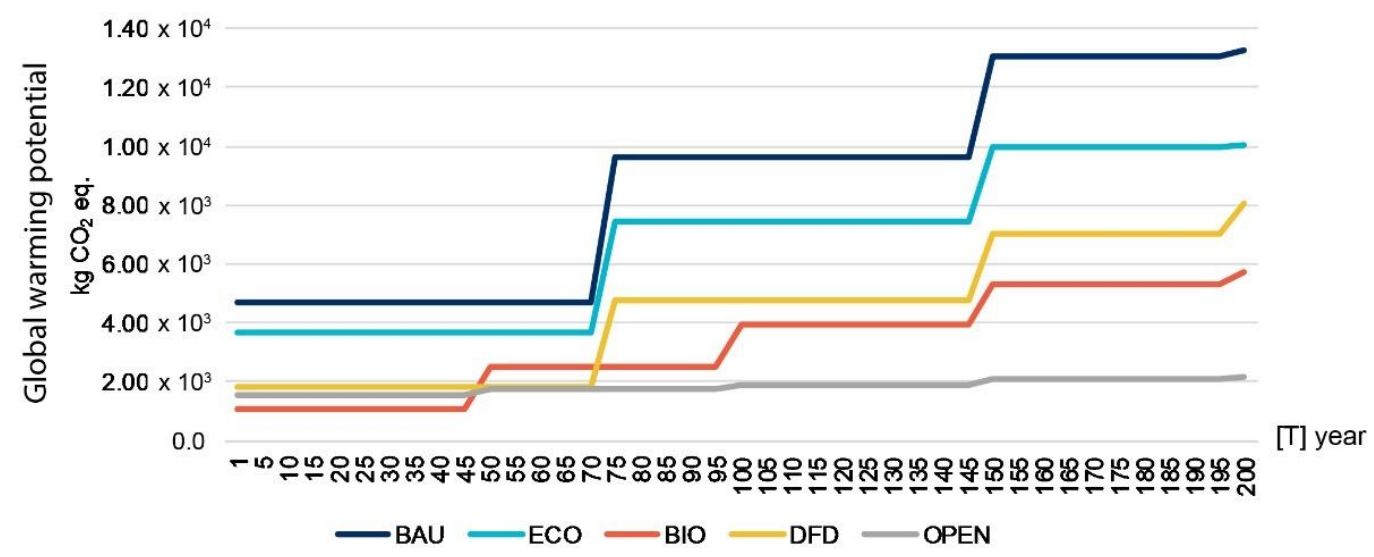

Figure 2. Cumulative GWP for the structural design variants over 200 years.

The LCA and MFA results show that the OPEN structure (i.e., the use of durable materials in a lean design that is used in the same location for as long as possible by facilitating temporal adaptations and multiple cycles (reuse, refurbish, recycle) before final disposal) leads to the lowest environmental impacts, material import and material consumption in the long term. This is because the amount of the impact-intensive concrete has partially been substituted with lightweight and low-impact timber in-fills that facilitate easier adaptations, potentially prolonging the structure's use. However, life prolongation, can be achieved through a variety of different design solutions. For example, the concrete elements of the DFD structure are also designed for a longer functional lifespan and the structure also uses a mix of primary and secondary concrete elements. However, the DFD does not match the OPEN structure's performance. Therefore, it cannot be claimed that life prolongation alone implies a universal gain in all cases. It suggests that the material design is presumably equally as important for the environmental and resource performance as the life-prolonging design solution.

In the short term, the best GWP performance comes from the BIO (i.e., the use of low-impact biomaterials such as wood), OPEN (i.e., the use of a lean design) and DFD structure (i.e., the use of secondary materials) while facilitating multiple cycles (i.e., reuse, recycle, recover). This is due to a favorable balance between: impacts $/ \mathrm{kg}$, technical lifespan, amount needed compared to virgin and non-renewable materials. Thus, the use of biomaterials, lean design and secondary materials could focus on up-front reductions of shorter-lived environmentally intensive building components and make the benefit of reuse, recycling and recovery available sooner.

It was also found that optimizing the BAU by applying a leaner design that is recyclable (ECO) can also reduce the environmental impact and material consumption. However, the optimization potential is limited compared to the complete redesign of the other variants as the ECO still builds on a business-as-usual practice.

\subsection{Results of the Sensitivity Analysis}

The sensitivity analysis informs on the robustness of the variants' performance in different circular scenarios in terms of the high level of uncertainty introduced by the multi-cycling aspect far into the future. Figures 3 and 4 show the accumulated GWP and MFA results respectively of the sensitivity scenarios compared to the baseline scenario of each structural variant. Supplementary Materials Figure S4 shows more detailed graphs.

Altering the number of cycles (e.g., adding or removing a cycle) affects the variant's LCA performance in terms of the share of impact distributed between the cycles. It also affects the MFA in terms of what happens to the materials after they leave the structure. The results show that adding one cycle $(C+1)$ improves the GWP performance of all the variants although the improvement is minor for the BIO and DFD. An extra cycle also increases the amount of reusable material of the BAU, ECO, BIO and OPEN whereas the amount stays the same for the DFD as it already contains reusable material. For the DFD the 
removal of one reuse cycle results in the same GWP performance as for the baseline scenario, whereas the removal of two cycles results in a slightly worse performance. Furthermore, removing one or two cycles decreases the amount of reusable material and increases the amount of recyclable material of the DFD.
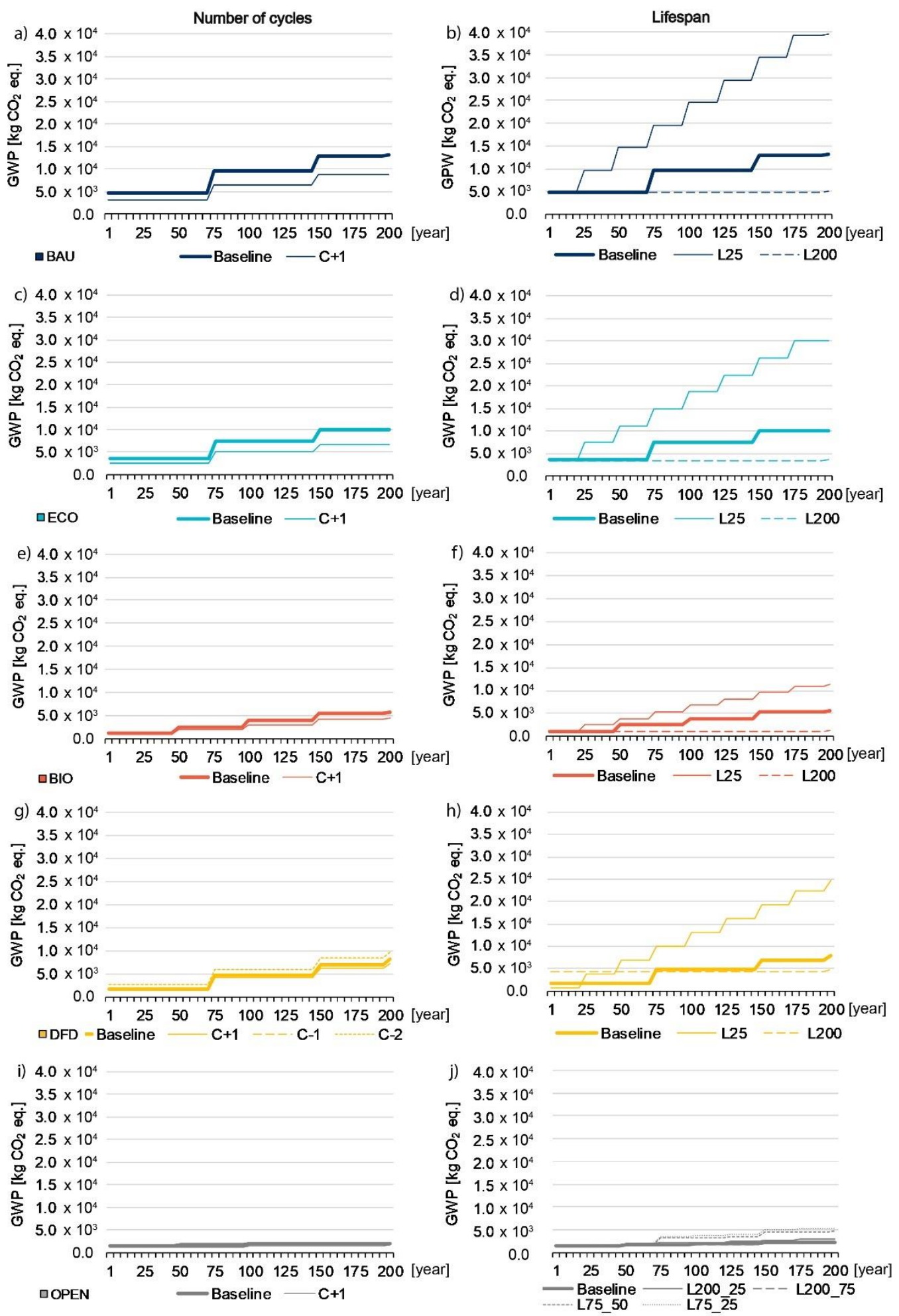

Figure 3. Cumulative GWP for the baseline and sensitivity scenarios from Table 1 of the structural variants. Abbreviations: $\mathrm{L}=$ lifespan, $\mathrm{C}=$ number of cycles. 

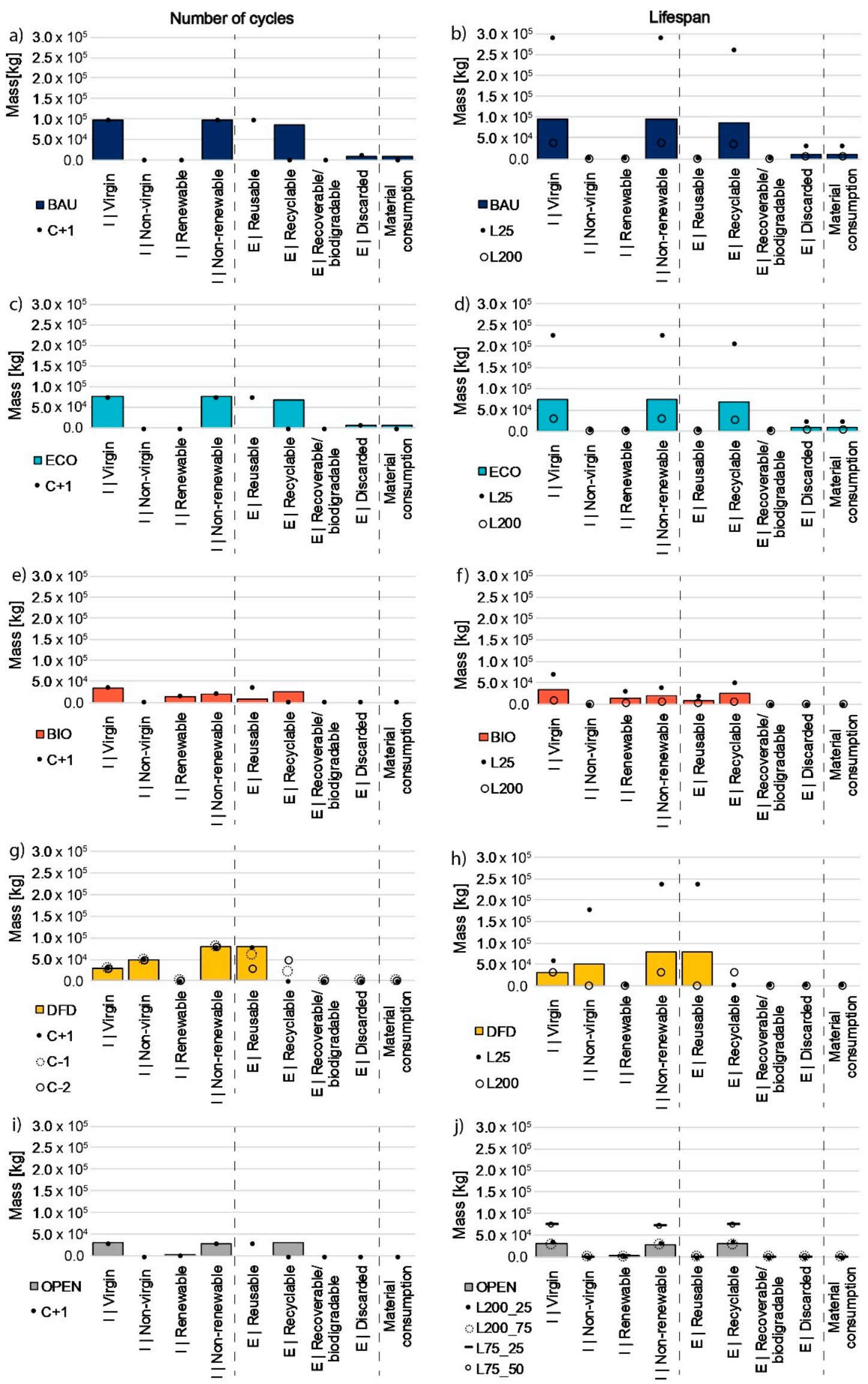

Figure 4. Material flow analysis results for the baseline and sensitivity scenarios from Table 1 of the structural variants. Abbreviations: $\mathrm{L}=$ lifespan, $\mathrm{C}=$ number of cycles. 
Extending the functional lifespan to 200 years improves the GWP and decreases the amount of material proportionally of the BAU, ECO, BIO and DFD because the variants are only produced once within 200 years instead of every 75 years for the BAU, ECO and DFD and every 50 years for the BIO. However, the DFD L200 has a higher GWP than the baseline in the first 75 years. Figure 4 shows that, for the DFD baseline scenario, the structure is built from a mix of primary and secondary prefabricated concrete elements. After 75 years, all of the concrete elements are transported for reuse elsewhere. When the DFD structure's lifespan is extended from 75 years to 200 years, the concrete elements are used for a longer time within the DFD. Consequently, this reduces the number of times the elements can be subsequently reused. Hence, a larger share of the GWP is allocated to the DFD. Furthermore, non-virgin elements have a shorter lifespan than virgin elements. Thus, to ensure a longer use of the elements in the DFD, all of the prefabricated concrete elements need to be virgin which increases the amount of virgin material and recyclable material, and decreases the amount of non-virgin material and reusable material of the variant. This creates a higher up-front GWP but over 200 years the GWP is much lower compared to the baseline scenario. Fewer adaptations reduce GWP for the OPEN, whereas more adaptations increase the GWP. As the prefabricated concrete elements make up $92 \%$ of the OPEN structure's mass, whereas the infill modules only make up $8 \%$, the changes in the infill modules' lifespans show a minor change in the material amounts.

A shorter functional lifespan of 25 years increases the GWP and material amounts proportionally for all the variants because they are produced more frequently than baseline scenario.

The OPEN structure provides the most consistent and beneficial reductions in GWP, material import and material consumption. Even with a reduced functional lifespan and increased amount of adaptations, the OPEN still performs better than any of the other variants and scenarios. The only scenario that surpasses the performance of the OPEN structure is when the BIO structure, like the OPEN structure, is used for 200 years.

The results show that additional cycles and longer use improve the performance of the variants while unfulfilled cycles and shorter use worsen the performance of the variants compared to the variants' baseline scenarios. Furthermore, the variants are in general more sensitive to changes in the variants' lifespan, especially if the lifespan is shorter than what is set in the baseline scenario, compared to the number of cycles.

\subsection{Environmental Design Guidelines for Circular Building Structure}

In this section, design guidelines for designing circular building components, that designers are recommended to consider in the early design phase, are quantitatively derived from the findings of the LCA and MFA. The environmental design guidelines consist of: (1) a "score-card" derived from ranking the LCA and MFA performance of the variants and scenarios, (2) "rules-of-thumb" derived from comparing the savings of "pure" circular principles and (3) "nine rules" for designing circular building components identified from the lessons learned from comparing the variant's and scenario's LCA and MFA results.

\subsubsection{Score-Card}

Table 3 shows the variants' and scenarios' average percentage saving compared to the BAU baseline. The environmental performance of the variants and scenarios can significantly differ from one environmental impact category or material flow type to the other making it difficult to determine which variant or scenario performs best. Hence, in Table 3 the variants and scenarios are ranked based on the average percentage saving of (1) all environmental impacts and the material flows and (2) the GWP and the material flows. 
Table 3. Ranking of design variants and scenarios based on the average percentage LCA and MFA savings compared to the BAU (baseline).

\begin{tabular}{|c|c|c|c|c|c|c|c|c|c|c|c|c|c|c|c|c|c|c|c|c|c|c|c|c|c|}
\hline \multirow{2}{*}{\multicolumn{2}{|c|}{ Percentage Savings }} & \multicolumn{4}{|c|}{ BAU } & \multicolumn{4}{|c|}{ ECO } & \multicolumn{4}{|c|}{ BIO } & \multicolumn{6}{|c|}{ DFD } & \multicolumn{6}{|c|}{ OPEN } \\
\hline & & 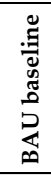 & 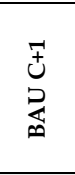 & 莡 & 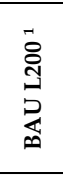 & 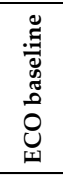 & $\begin{array}{l}\vec{J} \\
0 \\
0 \\
\end{array}$ & 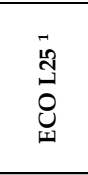 & $\begin{array}{l}\underset{\text { Iิ }}{0} \\
\text { ర్త }\end{array}$ & 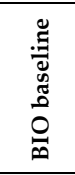 & $\begin{array}{l}\vec{t} \\
O \\
\stackrel{0}{\infty}\end{array}$ & $\begin{array}{l}\stackrel{ }{a} \\
\stackrel{0}{0}\end{array}$ & 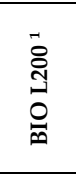 & 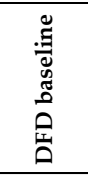 & $\begin{array}{l}\vec{y} \\
\pm \\
\text { 国 } \\
0\end{array}$ & $\begin{array}{l}\vec{u} \\
\text { 品 }\end{array}$ & 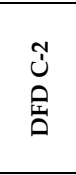 & 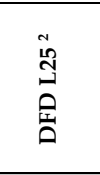 & $\begin{array}{l}\text { 옥 } \\
\text { 量 }\end{array}$ & 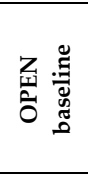 & 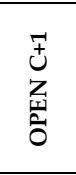 & 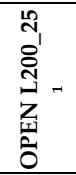 & 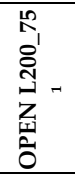 & 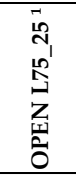 & 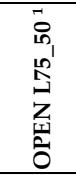 \\
\hline \multirow{11}{*}{ త్త } & GWP & $0 \%$ & $33 \%$ & $-200 \%$ & $63 \%$ & $24 \%$ & $49 \%$ & $-128 \%$ & $72 \%$ & $57 \%$ & $67 \%$ & $14 \%$ & $89 \%$ & $39 \%$ & $46 \%$ & $36 \%$ & $27 \%$ & $-87 \%$ & $64 \%$ & $84 \%$ & $87 \%$ & $78 \%$ & $86 \%$ & $65 \%$ & $61 \%$ \\
\hline & ODP & $0 \%$ & $31 \%$ & $-200 \%$ & $63 \%$ & $30 \%$ & $52 \%$ & $-108 \%$ & $74 \%$ & $-21 \%$ & $9 \%$ & $-142 \%$ & $70 \%$ & $-46 \%$ & $-28 \%$ & $-54 \%$ & $-60 \%$ & $-484 \%$ & $59 \%$ & $76 \%$ & $82 \%$ & $62 \%$ & $80 \%$ & $57 \%$ & $48 \%$ \\
\hline & POCP & $0 \%$ & $31 \%$ & $-200 \%$ & $63 \%$ & $27 \%$ & $50 \%$ & $-120 \%$ & $73 \%$ & $-44 \%$ & $-11 \%$ & $-189 \%$ & $64 \%$ & $12 \%$ & $22 \%$ & $9 \%$ & $1 \%$ & $-191 \%$ & $54 \%$ & $65 \%$ & $75 \%$ & $41 \%$ & $73 \%$ & $43 \%$ & $27 \%$ \\
\hline & $\mathrm{AP}$ & $0 \%$ & $32 \%$ & $-200 \%$ & $63 \%$ & $27 \%$ & $50 \%$ & $-120 \%$ & $73 \%$ & $3 \%$ & $25 \%$ & $-95 \%$ & $76 \%$ & $26 \%$ & $34 \%$ & $24 \%$ & $16 \%$ & $-142 \%$ & $61 \%$ & $75 \%$ & $82 \%$ & $61 \%$ & $80 \%$ & $56 \%$ & $46 \%$ \\
\hline & $\mathrm{ADPe}$ & $0 \%$ & $30 \%$ & $-200 \%$ & $63 \%$ & $26 \%$ & $48 \%$ & $-121 \%$ & $72 \%$ & $-30 \%$ & $2 \%$ & $-160 \%$ & $67 \%$ & $-34 \%$ & $-19 \%$ & $-41 \%$ & $-49 \%$ & $-381 \%$ & $39 \%$ & $69 \%$ & $77 \%$ & $51 \%$ & $76 \%$ & $46 \%$ & $33 \%$ \\
\hline & ADPf & $0 \%$ & $31 \%$ & $-200 \%$ & $63 \%$ & $28 \%$ & $51 \%$ & $-115 \%$ & $73 \%$ & $2 \%$ & $26 \%$ & $-96 \%$ & $75 \%$ & $-14 \%$ & $-1 \%$ & $-20 \%$ & $-27 \%$ & $-326 \%$ & $56 \%$ & $77 \%$ & $83 \%$ & $64 \%$ & $81 \%$ & $57 \%$ & $49 \%$ \\
\hline & $\begin{array}{l}\text { FAETP } \\
\end{array}$ & $0 \%$ & $32 \%$ & $-200 \%$ & $63 \%$ & $41 \%$ & $60 \%$ & $-76 \%$ & $78 \%$ & $28 \%$ & $44 \%$ & $-44 \%$ & $82 \%$ & $36 \%$ & $43 \%$ & $39 \%$ & $32 \%$ & $-65 \%$ & $54 \%$ & $80 \%$ & $85 \%$ & $70 \%$ & $84 \%$ & $64 \%$ & $56 \%$ \\
\hline & HTP & $0 \%$ & $29 \%$ & $-200 \%$ & $63 \%$ & $33 \%$ & $52 \%$ & $-100 \%$ & $75 \%$ & $9 \%$ & $31 \%$ & $-81 \%$ & $77 \%$ & $-15 \%$ & $-3 \%$ & $-16 \%$ & $-23 \%$ & $-254 \%$ & $29 \%$ & $76 \%$ & $81 \%$ & $62 \%$ & $80 \%$ & $54 \%$ & $45 \%$ \\
\hline & MAETP & $0 \%$ & $31 \%$ & $-200 \%$ & $63 \%$ & $31 \%$ & $53 \%$ & $-106 \%$ & $74 \%$ & $7 \%$ & $29 \%$ & $-85 \%$ & $77 \%$ & $32 \%$ & $39 \%$ & $32 \%$ & $24 \%$ & $-86 \%$ & $52 \%$ & $75 \%$ & $81 \%$ & $61 \%$ & $80 \%$ & $55 \%$ & $45 \%$ \\
\hline & TETP & $0 \%$ & $33 \%$ & $-200 \%$ & $63 \%$ & $23 \%$ & $48 \%$ & $-132 \%$ & $71 \%$ & $76 \%$ & $81 \%$ & $52 \%$ & $94 \%$ & $60 \%$ & $64 \%$ & $59 \%$ & $49 \%$ & $17 \%$ & $63 \%$ & $86 \%$ & $88 \%$ & $82 \%$ & $87 \%$ & $67 \%$ & $64 \%$ \\
\hline & Av. saving LCA & $0 \%$ & $31 \%$ & $-200 \%$ & $63 \%$ & $29 \%$ & $51 \%$ & $-113 \%$ & $73 \%$ & $6 \%$ & $29 \%$ & $-87 \%$ & $77 \%$ & $12 \%$ & $22 \%$ & $9 \%$ & $1 \%$ & $-190 \%$ & $53 \%$ & $76 \%$ & $82 \%$ & $63 \%$ & $80 \%$ & $56 \%$ & $47 \%$ \\
\hline \multirow{4}{*}{$\stackrel{\mathbb{L}}{\Sigma}$} & Import | Total material & $0 \%$ & $0 \%$ & $-200 \%$ & $63 \%$ & $22 \%$ & $22 \%$ & $-135 \%$ & $71 \%$ & $64 \%$ & $64 \%$ & $29 \%$ & $91 \%$ & $18 \%$ & $18 \%$ & $18 \%$ & $18 \%$ & $-146 \%$ & $69 \%$ & $69 \%$ & $69 \%$ & $64 \%$ & $71 \%$ & $20 \%$ & $25 \%$ \\
\hline & Import | Virgin & $0 \%$ & $0 \%$ & $0 \%$ & $0 \%$ & $0 \%$ & $0 \%$ & $0 \%$ & $0 \%$ & $0 \%$ & $0 \%$ & $0 \%$ & $0 \%$ & $63 \%$ & $63 \%$ & $63 \%$ & $63 \%$ & $75 \%$ & $0 \%$ & $0 \%$ & $0 \%$ & $0 \%$ & $0 \%$ & $0 \%$ & $0 \%$ \\
\hline & Material consumption & $0 \%$ & $100 \%$ & $-200 \%$ & $63 \%$ & $22 \%$ & $100 \%$ & $-135 \%$ & $71 \%$ & $100 \%$ & $100 \%$ & $100 \%$ & $100 \%$ & $100 \%$ & $100 \%$ & $100 \%$ & $100 \%$ & $100 \%$ & $100 \%$ & $100 \%$ & $100 \%$ & $100 \%$ & $100 \%$ & $100 \%$ & $100 \%$ \\
\hline & Av. saving MFA & $0 \%$ & $40 \%$ & $-80 \%$ & $25 \%$ & $9 \%$ & $44 \%$ & $-54 \%$ & $28 \%$ & $61 \%$ & $61 \%$ & $54 \%$ & $67 \%$ & $56 \%$ & $56 \%$ & $56 \%$ & $56 \%$ & $26 \%$ & $54 \%$ & $55 \%$ & $55 \%$ & $54 \%$ & $55 \%$ & $45 \%$ & $45 \%$ \\
\hline \multicolumn{2}{|c|}{ Av. saving LCA + MFA } & $0 \%$ & $36 \%$ & $-140 \%$ & $44 \%$ & $19 \%$ & $48 \%$ & $-84 \%$ & $51 \%$ & $34 \%$ & $45 \%$ & $-17 \%$ & $72 \%$ & $34 \%$ & $39 \%$ & $33 \%$ & $29 \%$ & $-82 \%$ & $54 \%$ & $65 \%$ & $68 \%$ & $59 \%$ & $68 \%$ & $50 \%$ & $46 \%$ \\
\hline \multicolumn{2}{|c|}{ Av. saving GWP + MFA } & $0 \%$ & $36 \%$ & $-140 \%$ & $44 \%$ & $16 \%$ & $47 \%$ & $-91 \%$ & $50 \%$ & $59 \%$ & $64 \%$ & $34 \%$ & $78 \%$ & $47 \%$ & $51 \%$ & $46 \%$ & $42 \%$ & $-31 \%$ & $59 \%$ & $69 \%$ & $71 \%$ & $66 \%$ & $70 \%$ & $55 \%$ & $53 \%$ \\
\hline \multicolumn{2}{|c|}{ Av. rank LCA + MFA } & 20 & 14 & 24 & 12 & 19 & 9 & 23 & 7 & 16 & 11 & 21 & 1 & 15 & 13 & 17 & 18 & 22 & 6 & 4 & 2 & 5 & 3 & 8 & 10 \\
\hline \multicolumn{2}{|c|}{ Av. rank GWP + MFA } & 21 & 18 & 24 & 16 & 20 & 14 & 23 & 12 & 7 & 6 & 19 & 1 & 13 & 11 & 15 & 17 & 22 & 8 & 4 & 2 & 5 & 3 & 9 & 10 \\
\hline
\end{tabular}

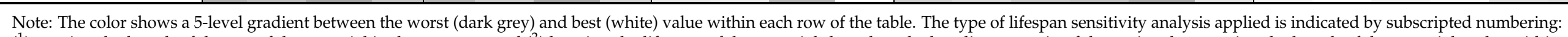

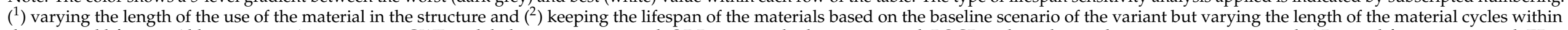

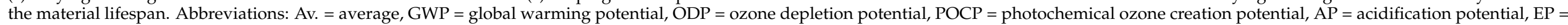

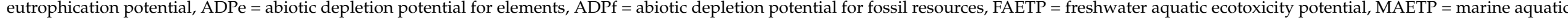
ecotoxicity potential, $\mathrm{HTP}=$ human toxicity potential, TETP = terrestrial ecotoxicity potential. 
Based on the ranking from Table 3, the "pure" circular pathways (i.e., baseline scenarios) and sensitivity scenarios for the structure are listed in accordance with their rank in Table 4. Designers can use the score-card in the design phase to identify circular pathways and strategy combinations in the technical, industrial and business model which leads to a good environmental and resource performance.

Table 4. Scorecard of the "pure" circular pathways, circular design variants and scenarios and their applied design principles.

\begin{tabular}{|c|c|c|c|c|c|c|}
\hline & Ra & ing & & Applied Des & gn Principle & \\
\hline & $\begin{array}{l}\text { LCA + } \\
\text { MFA }\end{array}$ & $\begin{array}{l}\text { GWP + } \\
\text { MFA }\end{array}$ & Variant/Scenario & Technical Model & Industrial Model & $\begin{array}{c}\text { Business } \\
\text { Model }\end{array}$ \\
\hline & 1 & 1 & OPEN baseline & $\begin{array}{c}\text { Adaptable (50 years between } \\
\text { adaptations), durable materials, } \\
\text { standard sized parts, multiple cycles } \\
\text { (reuse, recycling), very long lifespan } \\
\text { (200 years) }\end{array}$ & $\begin{array}{l}\text { Maintenance, } \\
\text { updates, reuse by } \\
\text { client, recycling by } \\
\text { third party }\end{array}$ & $\begin{array}{l}\text { Sale, } \\
\text { maintenance } \\
\text { and update } \\
\text { service }\end{array}$ \\
\hline 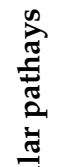 & 2 & 3 & DFD baseline & $\begin{array}{c}\text { Standard sized parts, durable } \\
\text { materials, demountable parts, } \\
\text { reusable parts, multiple cycles (reuse, } \\
\text { recycle) }\end{array}$ & $\begin{array}{l}\text { Reuse by provider } \\
\text { or client, recycling } \\
\text { by third party }\end{array}$ & $\begin{array}{c}\text { Sale with } \\
\text { takeback, or } \\
\text { sale and re-sale }\end{array}$ \\
\hline 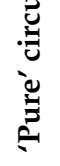 & 3 & 2 & BIO baseline & $\begin{array}{l}\text { Biomaterials, multiple cycles (reuse, } \\
\text { recycle, recover), long lifespan } \\
\text { (50 years) }\end{array}$ & $\begin{array}{l}\text { Open-loop } \\
\text { recycling and } \\
\text { incineration by } \\
\text { third party }\end{array}$ & Sale \\
\hline & 4 & 4 & ECO baseline & Lean design, long lifespan (75 years) & $\begin{array}{l}\text { Open-loop } \\
\text { recycling and } \\
\text { landfill by third } \\
\text { party }\end{array}$ & Sale \\
\hline & 5 & 5 & BAU baseline & Linear design, long lifespan (75 years) & $\begin{array}{l}\text { Open-loop } \\
\text { recycling and } \\
\text { landfill by third } \\
\text { party }\end{array}$ & Sale \\
\hline & 1 & 1 & BIO L200 ${ }^{1}$ & $\begin{array}{c}\text { Biomaterials, multiple cycles (reuse, } \\
\text { recycle, recover), very long lifespan } \\
\text { ( } 200 \text { years) }\end{array}$ & $\begin{array}{l}\text { Open-loop } \\
\text { recycling and } \\
\text { incineration by } \\
\text { third party }\end{array}$ & Sale \\
\hline 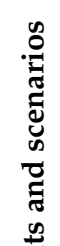 & 2 & 2 & OPEN C +1 & $\begin{array}{c}\text { Adaptable (50 years between } \\
\text { adaptations), durable materials, } \\
\text { standard sized parts, multiple cycles } \\
\text { (reuse, recycling), very long lifespan } \\
\text { (200 years for the concrete structure), } 1 \\
\text { additional cycle (reuse) }\end{array}$ & $\begin{array}{l}\text { Maintenance, } \\
\text { updates, reuse by } \\
\text { client, recycling by } \\
\text { third party }\end{array}$ & $\begin{array}{l}\text { Sale, } \\
\text { maintenance } \\
\text { and update } \\
\text { service }\end{array}$ \\
\hline 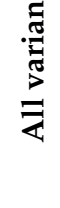 & 3 & 3 & OPEN L200_75 1 & $\begin{array}{l}\text { Adaptable (75 years between } \\
\text { adaptations), durable materials, } \\
\text { standard sized parts, multiple cycles } \\
\text { (reuse, recycling), very long lifespan } \\
\text { (200 years for the concrete structure) }\end{array}$ & $\begin{array}{l}\text { Maintenance, } \\
\text { updates, reuse by } \\
\text { client, recycling by } \\
\text { third party }\end{array}$ & $\begin{array}{c}\text { Sale, } \\
\text { maintenance } \\
\text { and update } \\
\text { service }\end{array}$ \\
\hline & 4 & 4 & OPEN baseline & $\begin{array}{l}\text { Adaptable (50 years between } \\
\text { adaptations), durable materials, } \\
\text { standard sized parts, multiple cycles } \\
\text { (reuse, recycling), very long lifespan } \\
\text { (200 years for the concrete structure) }\end{array}$ & $\begin{array}{l}\text { Maintenance, } \\
\text { updates, reuse by } \\
\text { client, recycling by } \\
\text { third party }\end{array}$ & $\begin{array}{c}\text { Sale, } \\
\text { maintenance } \\
\text { and update } \\
\text { service }\end{array}$ \\
\hline
\end{tabular}


Table 4. Cont.

\begin{tabular}{|c|c|c|c|c|c|}
\hline \multicolumn{2}{|c|}{ Ranking } & \multirow[b]{2}{*}{ Variant/Scenario } & \multicolumn{3}{|c|}{ Applied Design Principle } \\
\hline $\begin{array}{l}\text { LCA + } \\
\text { MFA }\end{array}$ & $\begin{array}{l}\text { GWP + } \\
\text { MFA }\end{array}$ & & Technical Model & Industrial Model & $\begin{array}{l}\text { Business } \\
\text { Model }\end{array}$ \\
\hline 5 & 5 & OPEN L200_25 ${ }^{1}$ & $\begin{array}{l}\text { Adaptable ( } 25 \text { years between } \\
\text { adaptations), durable materials, } \\
\text { standard sized parts, multiple cycles } \\
\text { (reuse, recycling), very long lifespan } \\
\text { (200 years for the concrete structure) }\end{array}$ & $\begin{array}{l}\text { Maintenance, } \\
\text { updates, reuse by } \\
\text { client, recycling by } \\
\text { third party }\end{array}$ & $\begin{array}{l}\text { Sale, } \\
\text { maintenance } \\
\text { and update } \\
\text { service }\end{array}$ \\
\hline 6 & 8 & DFD L200 2 & $\begin{array}{l}\text { Standard sized parts, durable } \\
\text { materials, demountable parts, } \\
\text { reusable parts, multiple cycles (reuse, } \\
\text { recycle), very long lifespan (200 years) }\end{array}$ & $\begin{array}{l}\text { Reuse by provider } \\
\text { or client, recycling } \\
\text { by third party }\end{array}$ & $\begin{array}{c}\text { Sale with } \\
\text { takeback, or } \\
\text { sale and re-sale }\end{array}$ \\
\hline 7 & 12 & ECO L200 ${ }^{1}$ & Lean design, long lifespan (200 years) & $\begin{array}{l}\text { Open-loop } \\
\text { recycling and } \\
\text { landfill by third } \\
\text { party }\end{array}$ & Sale \\
\hline 8 & 9 & OPEN L75_25 ${ }^{1}$ & $\begin{array}{l}\text { Adaptable ( } 25 \text { years between } \\
\text { adaptations), durable materials, } \\
\text { standard sized parts, multiple cycles } \\
\text { (reuse, recycling), long lifespan ( } 75 \\
\text { years for the concrete structure) }\end{array}$ & $\begin{array}{l}\text { Maintenance, } \\
\text { updates, reuse by } \\
\text { client, recycling by } \\
\text { third party }\end{array}$ & $\begin{array}{l}\text { Sale, } \\
\text { maintenance } \\
\text { and update } \\
\text { service }\end{array}$ \\
\hline 9 & 14 & $\mathrm{ECO} C+1$ & Lean design, 1 additional cycle (reuse) & $\begin{array}{l}\text { Local reuse, } \\
\text { open-loop recycling } \\
\text { and landfill by } \\
\text { third party }\end{array}$ & Sale \\
\hline 10 & 10 & OPEN L75_50 ${ }^{1}$ & $\begin{array}{l}\text { Adaptable (59 years between } \\
\text { adaptations), durable materials, } \\
\text { standard sized parts, multiple cycles } \\
\text { (reuse, recycling), long lifespan (75 } \\
\text { years for the concrete structure) }\end{array}$ & $\begin{array}{l}\text { Maintenance, } \\
\text { updates, reuse by } \\
\text { client, recycling by } \\
\text { third party }\end{array}$ & $\begin{array}{l}\text { Sale, } \\
\text { maintenance } \\
\text { and update } \\
\text { service }\end{array}$ \\
\hline 11 & 6 & $\mathrm{BIO} \mathrm{C}+1$ & $\begin{array}{l}\text { Biomaterials, multiple cycles (reuse, } \\
\text { recycle, recover), } 1 \text { additional cycle } \\
\text { (reuse) }\end{array}$ & $\begin{array}{l}\text { Local reuse, } \\
\text { open-loop recycling } \\
\text { and incineration by } \\
\text { third party }\end{array}$ & Sale \\
\hline 12 & 16 & BAU L200 ${ }^{1}$ & $\begin{array}{c}\text { Linear design, very long lifespan (200 } \\
\text { years) }\end{array}$ & $\begin{array}{l}\text { Open-loop } \\
\text { recycling and } \\
\text { landfill by third } \\
\text { party }\end{array}$ & Sale \\
\hline 13 & 11 & $\mathrm{DFD} C+1$ & $\begin{array}{l}\text { Standard sized parts, durable } \\
\text { materials, demountable parts, } \\
\text { reusable parts, multiple cycles (reuse, } \\
\text { recycle), } 1 \text { additional cycle (reuse) }\end{array}$ & $\begin{array}{l}\text { Reuse by provider } \\
\text { or client, recycling } \\
\text { by third party }\end{array}$ & $\begin{array}{c}\text { Sale with } \\
\text { takeback, or } \\
\text { sale and re-sale }\end{array}$ \\
\hline 14 & 18 & BAU C +1 & $\begin{array}{c}\text { Linear design }+1 \text { additional cycle } \\
\text { (reuse) }\end{array}$ & $\begin{array}{l}\text { Local reuse, } \\
\text { open-loop recycling } \\
\text { and landfill by } \\
\text { third party }\end{array}$ & Sale \\
\hline 15 & 13 & DFD baseline & $\begin{array}{c}\text { Standard sized parts, durable } \\
\text { materials, demountable parts, } \\
\text { reusable parts, multiple cycles (reuse, } \\
\text { recycle) }\end{array}$ & $\begin{array}{l}\text { Reuse by provider } \\
\text { or client, recycling } \\
\text { by third party }\end{array}$ & $\begin{array}{l}\text { Sale with } \\
\text { takeback, or } \\
\text { sale and re-sale }\end{array}$ \\
\hline
\end{tabular}


Table 4. Cont.

\begin{tabular}{|c|c|c|c|c|c|}
\hline \multicolumn{2}{|c|}{ Ranking } & \multirow[b]{2}{*}{ Variant/Scenario } & \multicolumn{3}{|c|}{ Applied Design Principle } \\
\hline $\begin{array}{l}\text { LCA + } \\
\text { MFA }\end{array}$ & $\begin{array}{l}\text { GWP + } \\
\text { MFA }\end{array}$ & & Technical Model & Industrial Model & $\begin{array}{l}\text { Business } \\
\text { Model }\end{array}$ \\
\hline 16 & 7 & BIO baseline & $\begin{array}{c}\text { Biomaterials, multiple cycles (reuse, } \\
\text { recycle, recover), long lifespan ( } 50 \\
\text { years) }\end{array}$ & $\begin{array}{l}\text { Open-loop } \\
\text { recycling and } \\
\text { incineration by } \\
\text { third party }\end{array}$ & Sale \\
\hline 17 & 15 & DFD C-1 & $\begin{array}{l}\text { Standard sized parts, durable } \\
\text { materials, demountable parts, } \\
\text { reusable parts, multiple cycles (reuse, } \\
\text { recycle), } 1 \text { less cycle (reuse) }\end{array}$ & $\begin{array}{l}\text { Reuse by provider } \\
\text { or client, recycling } \\
\text { by third party }\end{array}$ & $\begin{array}{c}\text { Sale with } \\
\text { takeback, or } \\
\text { sale and re-sale }\end{array}$ \\
\hline 18 & 17 & DFD C-2 & $\begin{array}{l}\text { Standard sized parts, durable } \\
\text { materials, demountable parts, } \\
\text { reusable parts, multiple cycles (reuse, } \\
\text { recycle), } 2 \text { less cycles (reuse) }\end{array}$ & $\begin{array}{l}\text { Reuse by provider } \\
\text { or client, recycling } \\
\text { by third party }\end{array}$ & $\begin{array}{c}\text { Sale with } \\
\text { takeback, or } \\
\text { sale and re-sale }\end{array}$ \\
\hline 19 & 20 & ECO baseline & Lean design, long lifespan (75 years) & $\begin{array}{l}\text { Open-loop } \\
\text { recycling and } \\
\text { landfill by third } \\
\text { party }\end{array}$ & Sale \\
\hline 20 & 21 & BAU baseline & Linear design, long lifespan (75 years) & $\begin{array}{l}\text { Open-loop } \\
\text { recycling and } \\
\text { landfill by third } \\
\text { party }\end{array}$ & Sale \\
\hline 21 & 19 & $\mathrm{BIO} \mathrm{L}_{2} 5^{1}$ & $\begin{array}{l}\text { Biomaterials, multiple cycles (reuse, } \\
\text { recycle, recover), short lifepan } \\
\text { ( } 25 \text { years })\end{array}$ & $\begin{array}{l}\text { Open-loop } \\
\text { recycling and } \\
\text { incineration by } \\
\text { third party }\end{array}$ & Sale \\
\hline 22 & 22 & DFD L25 2 & $\begin{array}{l}\text { Standard sized parts, durable } \\
\text { materials, demountable parts, } \\
\text { reusable parts, multiple cycles (reuse, } \\
\text { recycle), short lifespan ( } 25 \text { years) }\end{array}$ & $\begin{array}{l}\text { Reuse by provider } \\
\text { or client, recycling } \\
\text { by third party }\end{array}$ & $\begin{array}{c}\text { Sale with } \\
\text { takeback, or } \\
\text { sale and re-sale }\end{array}$ \\
\hline 23 & 23 & ECO L25 ${ }^{1}$ & Lean design, short lifespan ( 25 years) & $\begin{array}{l}\text { Open-loop } \\
\text { recycling and } \\
\text { landfill by third } \\
\text { party }\end{array}$ & Sale \\
\hline 24 & 24 & BAU L25 ${ }^{1}$ & $\begin{array}{l}\text { Linear design, short lifespan } \\
\text { (25 years) }\end{array}$ & $\begin{array}{c}\text { Open-loop } \\
\text { recycling and } \\
\text { landfill by third } \\
\text { party }\end{array}$ & Sale \\
\hline
\end{tabular}

Note: Type of lifespan sensitivity analysis applied: $\left({ }^{1}\right)$ varying the length of the use of the material in the structure and $\left({ }^{2}\right)$ keeping the lifespan of the materials based on the baseline scenario of the variant but varying the length of the material cycles within the material lifespan.

Table 4 shows that for the "pure" circular pathways, the two different ranking methods rank the OPEN, ECO and BAU similarly, but the DFD and BIO are ranked differently. Similar results are seen for the sensitivity scenarios. The different ranking is caused by the difference in the variants' and scenarios' average performance in the 11 impact categories compared with their performance in GWP. For example, the DFD has a higher average performance within all 11 impact indicators (12\%) and a lower average saving in GWP (39\%) compared to the BIO, which has a lower average performance within the 11 impact categories (6\%) but a higher average saving in GWP (57\%). Overall, the OPEN results in the best performance in both ranking methods. Although ECO is the only other variant, besides the OPEN, that obtains savings in all 11 impact categories compared to the BAU, it is only ranked number 4 while the DFD, which does not obtain savings in all impact categories, 
is ranked number 2. This is because the DFD performs much better in the MFA, as it is partially based on non-virgin material, while exporting reusable material whereas the ECO is based on virgin material and exports material for recycling and disposal. Thus, the ranking can provide a simpler decision basis that can support designers in the early design stage, but does not always represent the variants' performance within single indicators.

The ranking shows that focus on single optimizations (i.e., "pure" circular design pathways) does not lead to the best performance. Scenarios that combine different circular design options perform much better than the baseline scenarios. For example, the best performing scenario is the BIO L200, which combines biomaterials with multiple VRPs (i.e., reuse, recycle and recover) and a long functional lifespan of 200 years. Thus, optimizing the environmental impact and material consumption is not a matter of changing single design parameters (e.g., substituting concrete with bio-materials), but considering several design parameters in interrelation with each other (i.e., material amount, material type, lifespan, processes, life-cycles, VRPs and design strategies). This way of designing requires considering building components as a composite of sub-components, parts and materials each with different and multiple use- and life-cycles. This means that circular design options and design parameters need to be considered for each constituent of the component. However, due to the long temporal aspect and the uncertainty it creates, the right pairing of these parameters and the circular design options facilitated in the technical design of the structural variants and scenarios cannot be determined, realized or guaranteed without (re)designing the technical, industrial and business model integrally and in co-creation with all stakeholders in the supply chain.

\subsubsection{Rules-of-Thumb}

Table 5 provides rules-of-thumb for designing circular building components by indicating how much the environmental performance is reduced or increased when a specific circular design option is applied. The circular design principles which lead to consistent and significant savings in environmental impact and material flows are: adding cycles, life-extending design, and reducing the amount of materials used. Other circular design options (e.g., use of biomaterials, and modularity) are less consistent in their effect on the environmental performance as they could lead to both reduced and increased environmental impacts. The percentage reduction in material for a leaner variant saves (for the compared case) approximately the same percentage on impact. Designing for reuse, but not realizing the reuse cycle, would increase the environmental impact. The effect of not realizing a recycling cycle is minor. 
Table 5. Preliminary rules-of-thumb for designing circular building components based on comparisons of the Life Cycle Assessments (LCA) and Material Flow Analysis (MFA) results.

\begin{tabular}{|c|c|c|c|c|c|c|c|c|c|c|c|}
\hline & & \multicolumn{2}{|c|}{ LCA } & \multicolumn{5}{|c|}{ MFA } & \multicolumn{3}{|c|}{ Underlying Comparisons } \\
\hline & & 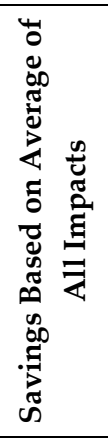 & 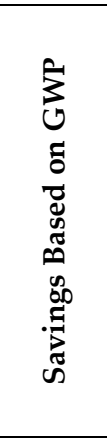 & 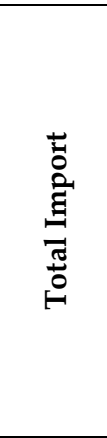 & 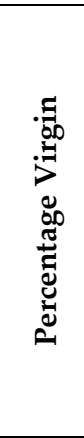 & 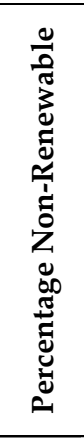 & 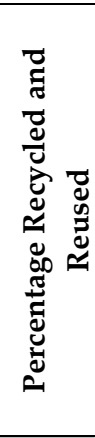 & 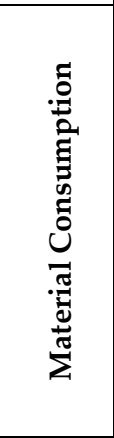 & 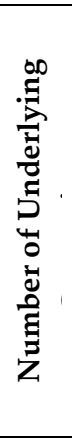 & 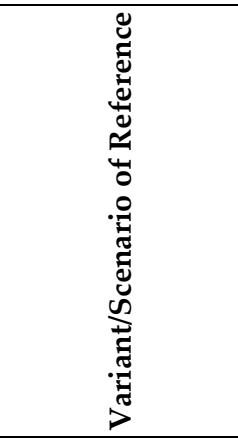 & 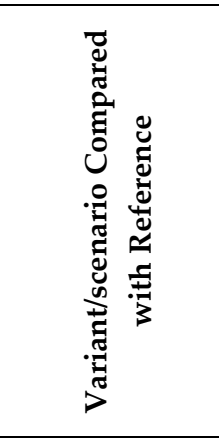 \\
\hline \multirow{3}{*}{$\begin{array}{l}\text { Adding one cycle (virgin } \\
\text { material) }\end{array}$} & Min. & $24 \%$ & $21 \%$ & $0 \%$ & $0 \%$ & $0 \%$ & $0 \%$ & $0 \%$ & \multirow{3}{*}{4} & \multirow{3}{*}{$\begin{array}{l}\text { Baseline of the } \\
\text { BAU, BIO, ECO } \\
\text { and OPEN }\end{array}$} & \multirow{3}{*}{$\begin{array}{c}\mathrm{C}+1 \text { of } \mathrm{BAU}, \\
\mathrm{ECO}, \mathrm{BIO} \text { and } \\
\text { OPEN }\end{array}$} \\
\hline & Av. & $28 \%$ & $28 \%$ & $0 \%$ & $0 \%$ & $0 \%$ & $5 \%$ & $50 \%$ & & & \\
\hline & Max. & $31 \%$ & $33 \%$ & $0 \%$ & $0 \%$ & $0 \%$ & $11 \%$ & $100 \%$ & & & \\
\hline Lean design & Av. & $29 \%$ & $24 \%$ & $22 \%$ & $0 \%$ & $0 \%$ & $0 \%$ & $22 \%$ & 1 & BAU baseline & ECO baseline \\
\hline Biomaterials & Av. & $6 \%$ & $57 \%$ & $64 \%$ & $0 \%$ & $43 \%$ & $11 \%$ & $100 \%$ & 1 & BAU baseline & BIO baseline \\
\hline \multirow{3}{*}{$\begin{array}{c}\text { Life extending design, } \\
\text { functional lifespan extension } \\
\text { from } 75 \text { to } 200 \text { years (virgin } \\
\text { material) }\end{array}$} & Min. & $63 \%$ & $63 \%$ & $63 \%$ & $0 \%$ & $0 \%$ & $0 \%$ & $0 \%$ & \multirow{3}{*}{3} & \multirow{3}{*}{$\begin{array}{c}\text { Baseline of } \\
\text { BAU, BIO and } \\
\text { ECO }\end{array}$} & \multirow{3}{*}{$\begin{array}{l}\text { L200 of BAU, } \\
\text { BIO and ECO }\end{array}$} \\
\hline & Av. & $67 \%$ & $67 \%$ & $67 \%$ & $0 \%$ & $0 \%$ & $0 \%$ & $42 \%$ & & & \\
\hline & Max. & $75 \%$ & $75 \%$ & $75 \%$ & $0 \%$ & $0 \%$ & $0 \%$ & $63 \%$ & & & \\
\hline \multirow{3}{*}{$\begin{array}{c}\text { Reducing the functional } \\
\text { lifespan from } 75 \text { to } 25 \text { years } \\
\text { (virgin material) }\end{array}$} & Min. & $-200 \%$ & $-200 \%$ & $-200 \%$ & $0 \%$ & $0 \%$ & $0 \%$ & $-200 \%$ & \multirow{3}{*}{3} & Baseline of & \multirow{3}{*}{$\begin{array}{l}\mathrm{L} 25 \text { of } \mathrm{BAU}, \\
\mathrm{BIO} \text { and } \mathrm{ECO}\end{array}$} \\
\hline & Av. & $-166 \%$ & $-166 \%$ & $-167 \%$ & $0 \%$ & $0 \%$ & $0 \%$ & $-133 \%$ & & BAU, BIO and & \\
\hline & Max. & $-100 \%$ & $-100 \%$ & $-100 \%$ & $0 \%$ & $0 \%$ & $0 \%$ & $0 \%$ & & $\mathrm{ECO}$ & \\
\hline Modularity & Av. & $12 \%$ & $39 \%$ & $18 \%$ & $63 \%$ & $0 \%$ & $11 \%$ & $100 \%$ & 1 & BAU baseline & DFD baseline \\
\hline \multirow{3}{*}{$\begin{array}{l}\text { Removing one reuse cycle } \\
\text { (virgin material) }\end{array}$} & Min. & $-46 \%$ & $-49 \%$ & $0 \%$ & $0 \%$ & $0 \%$ & $-10 \%$ & $0 \%$ & \multirow{3}{*}{4} & \multirow{3}{*}{$\begin{array}{l}\mathrm{C}+1 \text { of } \mathrm{BAU}, \\
\mathrm{ECO}, \mathrm{BIO} \text { and } \\
\text { OPEN }\end{array}$} & \multirow{3}{*}{$\begin{array}{c}\text { Baseline of } \\
\text { BAU, ECO, } \\
\text { BIO and OPEN }\end{array}$} \\
\hline & Av. & $-39 \%$ & $-39 \%$ & $0 \%$ & $0 \%$ & $0 \%$ & $-5 \%$ & $50 \%$ & & & \\
\hline & Max. & $-31 \%$ & $-27 \%$ & $0 \%$ & $0 \%$ & $0 \%$ & $0 \%$ & $100 \%$ & & & \\
\hline $\begin{array}{l}\text { Removing one recycling cycle } \\
\text { (virgin material) }\end{array}$ & Av. & $-3 \%$ & $-4 \%$ & $0 \%$ & $0 \%$ & $0 \%$ & $0 \%$ & $0 \%$ & 1 & DFD C-1 & DFD baseline \\
\hline
\end{tabular}

Note: The color shows a 5-level gradient between the worst (dark grey) and best (white) value within each row of the table.

\subsubsection{Nine Environmental Design Rules for Circular Building Components}

From the experience and analysis of the LCA and MFA results, nine rules for designing circular building components were induced in Table 6. Rules 1-7 provide guidance on how to design circular building components (i.e., considerations, dos and do-nots). Rules 8 and 9 conclude by providing advice on which design variants for circular building components are the most circular from an environmental perspective based on the case of the structure.

It was found that (1) realizing and securing "ideal" circular designs requires the design parameters and technical, industrial and business model to be developed integrally and in co-creation with the supply chain. For example, reuse of the DFD structure could require a supply chain partner to offer take-back services of the concrete elements to avoid premature disposal. (2) The results show that the CE benefits are time-dependent. Hence, $\mathrm{CE}$ entails considering the temporal aspect of building projects more extensively (i.e., all future cycles) than is currently the practice (e.g., production and maintenance). (3) From the results it is concluded that designing circular building components requires a different way of viewing the components where the building component is considered as a composite of sub-components, parts and materials with different and multiple use- and life-cycles. Thus, for each constituent of the component circular design options and design parameters needs to be considered. (4) The results show that optimizing single design parameters 
(e.g., material choices) can improve the environmental impact and material consumption upfront (e.g., substituting concrete with bio-materials in the BIO variant) but does not necessarily lead to a better environmental performance in the long term as one design parameter may affect another. For example, switching from concrete to wood increases the replacement rate of the BIO variant. Thus, all design parameters need to be considered in relation to one another. (5) In the same regard, facilitating multiple rather than single $\mathrm{CE}$ design options showed to improve the environmental performance of the variants. (6) The DFD variant showed significant transportation impacts related to the reuse of the heavy concrete elements for reuse. Therefore, impacts related to the transportation of bulky or heavy components should be optimized. For example, by finding alternative ways of transportation, optimizing the transportation route or reusing the components in the vicinity. (7) Optimizing a linear (business-as-usual) design, as done for the ECO variant, can reduce the material consumption and environmental impact but the gain is limited compared to complete redesign as presented in the other variants. (8) For a building component with a long lifespan, such as the structure, the best long-term performance was found for the OPEN structure where the design is lean, durable and facilitates continuous adaptations and multiple cycles before final disposal. However, in the case where the structure will not last long, it is (9) better to focus on achieving up-front reductions by applying a lean design, secondary materials or use low-impact bio-materials and make the benefit of reuse, recycling and recovery available sooner before final disposal.

Table 6. Nine environmental design rules for circular building components.

(1) (Re)design the technical, industrial and business model integrally and in co-creation with involved stakeholders.

(2) Consider in a project not only the present production but consider all future cycles.

(3) Consider building components as a composite of sub-components, parts and materials with different and multiple use- and life cycles. Determine circular design options and design parameters (i.e., material amount, material type, lifespan, processes, life-cycle(s), VRPs and design strategies) in the materialisation (of each constituent) of the building component.

(4) Consider all circular design parameters in interrelation with each other (e.g., material amount, material type, lifespan, processes, life-cycles, VRPs and design strategies). Merely substituting linear materials with more circular materials (e.g., biomaterials, low-impact, reused or recycled) does not necessarily result in a more circular building component.

(5) Combine circular design options as opposed to focusing on a single option. For example, facilitating multiple VRPs (reuse, repair, refurbish, recycle and recover).

(6) Optimise impacts related to transportation when the component is bulky or heavy (e.g., find another less burdensome means of transportation, optimise the transportation route or minimise transport through local reuse).

(7) Prefer complete re-design of a building component above optimising the current linear (business-as-usual) variant.

(8) For a building component with a long functional lifespan (e.g., the circular structure), the best environmentally performing design applies the following principles:

- $\quad$ Uses durable materials with a very long lifespan while keeping the design as lean as possible.

- Keeps the components and materials in place for as long as possible by facilitating adaptations and adjustments over time.

- Multiple cycles are organised and incentivised after end of use of the components and materials to prolong the use (e.g., reuse) and close the loop (e.g., recycling) before final disposal (e.g., energy recovery).

(9) If the component will not last long, then the best environmentally performing design for a building component (e.g., the circular structure) applies the following principles:

- Applies a lean design, secondary materials or uses low-impact biomaterials if they have a favourable balance between: impacts $/ \mathrm{kg}$, technical lifespan, amount needed compared to virgin and non-renewable materials.

- Multiple cycles are organised and incentivised after end of use of the components and materials to prolong the use (e.g., reuse) and close the loop (e.g., recycling) before final disposal (e.g., energy recovery).

\subsection{Results of the Expert Sessions}

Forty-nine experts and practitioners from academia, industry and government in the field of LCA, CE design and CE built environment evaluated the LCA and MFA results 
and the environmental design guidelines. The results of the expert sessions are shown in Supplementary Materials Table S1. In $57 \%$ of the expert sessions, the participants raised that the design guidelines overall did not deviate from existing assumptions and circular design strategies. However, individual aspects of individual guidelines were questioned in $43 \%$ of the expert sessions. These remarks were used to iteratively improve the design guidelines of which the majority of the suggested improvements were implemented. The remaining recommendations are elaborated on in the discussion section. An important concern raised was on the accuracy of the results, as the design guidelines are based/depend on assumptions reaching far into the future (i.e., very long lifespans and future cycles) that are associated with high uncertainty. Thus, in $43 \%$ of the expert sessions, it was argued that the guidelines' validity largely depends on the industry determining, documenting and realizing future cycles. Related to this, the experts suggested in $57 \%$ of the expert sessions that future cycles are beyond the practice and scope of building projects. The transparency of the applied LCA and MFA method, as well as the results and limitations of the study, were regarded as crucial for the validity of the design guidelines. To improve the certainty of the guidelines, rigorous sensitivity analysis of the circular design parameters was suggested and is included within the scope of this study. Improving the usability of the design guidelines was recommended in $71 \%$ of the sessions by making them less abstract, clarifying the terminology used and providing concrete examples and practical advice. In $41 \%$ of the sessions, it was stressed not only to induce the guidelines from the LCA, but to qualitatively derive them directly, and therefore the scorecard and rules-of-thumb were developed.

\section{Discussion and Conclusions}

Knowledge on which circular design options result in the optimum environmental performance to support design and decision-making is still lacking. It is suggested that a broader scope is needed to transition to a circular built environment to significantly reduce waste, resource use and environmental impacts emanating from the building industry. In this paper, environmental design guidelines for circular building components were developed by applying LCA and MFA to a case of a structure in a Danish context. The LCA and MFA assessed not only the environmental performance of each individual use- and life cycle of the building component but its entire chain of use- and life cycles. The design guidelines presented provide theoretical insight and concrete, practical support on how to design circular building components with a competitive environmental performance.

The circular design options assessed in this paper have also been suggested by others (e.g., bio-materials, secondary materials, longer use, lean design) [33,34]. In that regard, it is questionable whether there is a need for extending the scope of the LCA and MFA in terms of assessing and designing multi-cycling systems as it points to some of the same conclusions derived from existing methods. However, unlike other studies, the findings suggest that individual circular design options and design parameters cannot alone secure the most optimal environmental performance but rather effective combinations are needed. For example, for a long-lived structure, the best option combined a lean and durable design that facilitates adaptations and multiple cycles before final disposal. Furthermore, for a short-lived structure, the best option combined a lean, bio- or secondary materialbased design that facilitates multiple cycles before final disposal. Further investigation is needed to identify the most effective combinations of different circular design options and design parameters. Similarly, design for disassembly has been praised by others $[70,71]$ but in this paper, the DFD variant was found to be less beneficial due to the burdensome transportation of the concrete elements for reuse. However, it is possible that the benefits of the DFD will significantly increase if the transportation impacts are reduced by using a less burdensome means of transportation, optimising the transportation route or reduce the need for transportation through local reuse. 
Implementation of multi-cycling environmental impact assessment and the design guidelines could have significant implications in multiple areas: (1) LCA practice, (2) the building industry and (3) the circular approach in the building industry.

(1) The industry focus for structures is now often on material substitution (e.g., lightweight structures, bio-based alternatives such as CLT, design for disassembly and durability) and limited to consider only one cycle at a time, independently of one another. The findings of this paper suggest that this focus alone does not lead to optimum long-term environmental performance. Instead, for components with a long functional-technical lifespan, the design guidelines entail facilitating a combination of circular design options: a resource-efficient design, longer use through adaptable design, substituting high-impact materials with low-impact biomaterials and facilitating multiple cycles before final disposal.

(2) The LCA and MFA approaches used in this study are currently not included in the LCA standards or practice tools. Implementation of the method is not straightforward as it would require changing the LCA scope, the calculation method, and the datasets of the different LCA databases used by the building industry.

(3) It is stressed that the variants in this study are not proven concepts, but concept ideas about ideal circular solutions. As a result, the circularity facilitated in the technical design for the design variants spans over chains of cycles that happen at different points in time and in some cases far into the future. Some of the major challenges of facilitating circularity arise because building projects consist of multiple processes, functions and stakeholders that are subject to change over time [21] and do not necessarily run in sequence but in parallel. The long life of building components and materials increases the uncertainty of the circularity. Furthermore, the structural variant with the best environmental performance might not be the most viable variant for the building industry. Hence, to guarantee the circularity would require a completely different approach in the building industry, including new market mechanisms, business models, supply-chain dynamics and multidisciplinary stakeholder co-creation throughout the value chain. Furthermore, circularity calls for moving away from the current short-term "one-off" independent project focus to a long-term projecttranscending approach, where buildings are perceived as a composite of components, parts and materials with different and multiple use- and life cycles in a CE (i.e., to consider materials in different cycles).

The generalizability of the design guidelines is questionable for several reasons. Firstly, the performance of the variants is temporal and site-specific. The study presented relies on static LCA. Hence, dynamic factors (e.g., technological progress of resource and energy consumption, energy grid mix, waste management, design and innovation and production efficiency) during the variants' long service life that influence the environmental performance of the variants were not considered. For example, transportation was modelled using present-day datasets. The variants are also aimed at a Danish context. Secondly, the design guidelines are based on four long-lived circular building structures; however, many more $\mathrm{CE}$ design solutions exist. Hence, the design guidelines would benefit from further validation. To strengthen the derived design guidelines, further testing of circular building structures based on other CE pathways is needed. Furthermore, whether the design guidelines work in every case should be investigated and which (if any) only work in some cases. It is important to stress that different "rules" may apply for designing other short-lived and medium-lived circular building components. For example, the design guidelines for circular kitchen and facade variants of the joint project that this paper is a part of look slightly different [47]. For the kitchen and facades, the best design was durable, used bio- or secondary materials, facilitated easy maintenance and multiple cycles before final disposal. However, if multiple cycles cannot be facilitated the best design for the kitchen and façade was lean, used for as long as possible, used bio- or secondary materials that can be biodegraded or recycled. 
The outcome of the LCA and MFA resulting in the design guidelines also depends on the underlying method applied and assumptions in the LCI. Performing a scenario-based sensitivity analysis provided valuable insight into how the results may be influenced by important design parameters such as the number of cycles and the length of the lifespan. It is therefore recommended that future assessments, similar to the one performed herein, are combined with rigorous sensitivity analyses. Furthermore, the design guidelines rely on attributional LCA, where the environmental impacts that can be attributed to the building components were quantified [65]. Hence, the recommendations of this paper are only valid at the building component level and cannot be directly projected to the societal level (i.e., what is right for the building component is not necessarily right for society). This is an important consideration in order to move whole societies towards reaching sustainability goals. It is also important to notice that design principles which save impacts over time (e.g., life-prolonging design solutions such as "design for disassembly") do not necessarily reduce environmental impacts and resource consumption today. Subsequently, such principles might not facilitate nearing climate agendas such as the EU's 2030 and 2050 climate goals. Thus, both short-term and long-term solutions are needed. Additionally, allocating environmental impacts to future cycles, such as in this paper, may lead to greenwashing if impacts are unaccounted for and hinder "real" progress.

Other ranking methods, e.g., prevention-based single-indicator systems such as "eco cost" or "shadow cost" may lead to other conclusions than those presented in this paper. Furthermore, this study focused on evaluating the variants' circularity based on environmental performance. However, other circularity metrics exist (e.g., considering environmental performance in relation to economic performance) [72]. Therefore, multi-criteria assessment methods are needed to fully assess the circularity of a building component.

From the above, it is concluded that there are still various opportunities for further development, testing and implementation of the presented environmental design guidelines. However, the derived design guidelines are an important step to support the industry in developing "ideal" circular building components and they provide insight into the environmental effect of different combinations of circular design principles.

Supplementary Materials: The following are available online at https:/ / www.mdpi.com/article/10 .3390 / su13105621/s1, Figure S1: Flow diagrams of the design variants, Figure S2: Material Shares, Figure S3: Material Flow Analysis, Figure S4: Cumulative GWP of the design variants over 200 years, Table S1: Expert sessions.

Author Contributions: Conceptualization, L.C.M.E. and A.v.S.; data curation, L.C.M.E.; formal analysis, L.C.M.E. and L.K.S.; investigation, L.C.M.E.; methodology, L.C.M.E. and A.v.S.; project administration, L.C.M.E.; resources, L.C.M.E.; software, L.C.M.E.; supervision, M.B. and H.B.; validation, L.C.M.E.; visualization, L.C.M.E.; writing—original draft, L.C.M.E.; writing-review and editing, A.v.S., M.B. and H.B. All authors have read and agreed to the published version of the manuscript.

Funding: This research received no external funding.

Institutional Review Board Statement: Not applicable.

Informed Consent Statement: Informed consent was obtained from all subjects involved in the study.

Data Availability Statement: Data sharing is not applicable to this article.

Conflicts of Interest: The authors declare no conflict of interest.

\section{References}

1. Abergel, T.; Dulac, J.; Hamilton, I.; Jordan, M.; Pradeep, A.; International Energy Agency. Global Status Report for Buildings and Constructi on towards a Zero-Emissions, Efficient and Resilient Buildings and Constructi on Sector; United Nations Environment Programme: Nairobi, Kenya, 2019.

2. Circle Economy. The Circularity Gap Report-Closing the Circularity Gap in a 9\% World; Circle Economy: Amsterdam, The Netherlands, 2019. 
3. International Resource Panel. Assessing Global Resource Use: A Systems Approach to Resource Efficiency and Pollution Reduction (a Report of the International Resource Panel); United Nations Environment Programme: Nairoby, Kenya, 2017.

4. Remondis Shortage of Raw Materials. Available online: https://www.remondis-sustainability.com/en/sharing/shortage-ofraw-materials / (accessed on 16 November 2020).

5. Danish Technological Institute. Materialer i den Cirkulære Økonomi: Gips; Danish Technological Institute: Taastrup, Denmark, 2019.

6. GAB Report Sand Scarcity in the Construction Industry. Available online: https://www.gabreport.com/sand-scarcity-in-theconstruction-industry (accessed on 9 November 2020).

7. Gallego-Schmid, A.; Chen, H.M.; Sharmina, M.; Mendoza, J.M.F. Links between circular economy and climate change mitigation in the built environment. J. Clean. Prod. 2020, 260, 121115. [CrossRef]

8. Kylili, A.; Fokaides, P.A. Policy trends for the sustainability assessment of construction materials: A review. Sustain. Cities Soc. 2017, 35, 280-288. [CrossRef]

9. DBEIS and NS. Monthly Statistics of Building Materials and Components; DBEIS and NS: London, UK, 2019.

10. Bocken, N.M.P.; de Pauw, I.; Bakker, C.; van der Grinten, B. Product design and business model strategies for a circular economy. J. Ind. Prod. Eng. 2016, 33, 308-320. [CrossRef]

11. Geissdoerfer, M.; Savaget, P.; Bocken, N.M.P.; Hultink, E.J. The Circular Economy-A new sustainability paradigm? J. Clean. Prod. 2017, 143, 757-768. [CrossRef]

12. Ellen MacArthur Foundation. Circularity in the Built Environment: Case Studies; Ellen MacArthur Foundation: Cowes, UK, 2016.

13. Reike, D.; Vermeulen, W.J.V.; Witjes, S. The circular economy: New or Refurbished as CE 3.0?-Exploring Controversies in the Conceptualization of the Circular Economy through a Focus on History and Resource Value Retention Options. Resour. Conserv. Recycl. 2018, 135, 246-264. [CrossRef]

14. Blomsma, F.; Kjaer, L.; Pigosso, D.; McAloone, T.; Lloyd, S. Exploring Circular Strategy Combinations-Towards Understanding the Role of PSS. Procedia CIRP 2018, 69, 752-757. [CrossRef]

15. Hart, J.; Adams, K.; Giesekam, J.; Tingley, D.D.; Pomponi, F. Barriers and drivers in a circular economy: The case of the built environment. Procedia CIRP 2019, 80, 619-624. [CrossRef]

16. Kirchherr, J.; Reike, D.; Hekkert, M. Conceptualizing the circular economy: An analysis of 114 definitions. Resour. Conserv. Recycl. 2017, 127, 221-232. [CrossRef]

17. Eberhardt, L.C.M.; Birkved, M.; Birgisdottir, H. Building design and construction strategies for a circular economy. Archit. Eng. Des. Manag. 2020, 1-21. [CrossRef]

18. Pomponi, F.; Moncaster, A. Embodied carbon mitigation and reduction in the built environment-What does the evidence say? J. Environ. Manag. 2016, 181, 687-700. [CrossRef]

19. Mestre, A.; Cooper, T. Circular Product Design. A Multiple Loops Life Cycle Design Approach for the Circular Economy. Des. J. 2017, 20, S1620-S1635. [CrossRef]

20. Minunno, R.; O'Grady, T.; Morrison, G.; Gruner, R.; Colling, M. Strategies for Applying the Circular Economy to Prefabricated Buildings. Buildings 2018, 8, 125. [CrossRef]

21. Geldermans, R.J. Design for Change and Circularity-Accommodating Circular Material \& Product Flows in Construction. Energy Procedia 2016, 96, 301-311. [CrossRef]

22. European Commission. Circular Economy Principles for Buildings Design; European Commission: Brussels, Belgium, 2020.

23. Cheshire, D. Building Revolutions Applying the Circular Economy to the Built Environement; RIBA Publishing: Newcastle upon Tyne, UK, 2016.

24. Brad, G.; Ciarimboli, N. Design for Disassembly in the Built Environment: A Guide to Closed-Loop Design and Building; Pennsylvania State University: University Park, PA, USA, 2005.

25. Ness, D.A.; Xing, K. Toward a Resource-Efficient Built Environment: A Literature Review and Conceptual Model. J. Ind. Ecol. 2017, 21, 572-592. [CrossRef]

26. EN 15978. European Committee for Standardisation. Sustainability of Construction Works-Assessment of Environmental Performance of Buildings-Calculation Method; European Committee for Standardisation: Brussels, Belgium, 2011.

27. ISO 14040. Environmental Management-Life Cycle Assessment-Principles and Framework; International Organization for Standardization: Geneva, Switzerland, 2008.

28. ISO 14044. Environmental Management-Life Cycle Assessment-Requirements and Guidelines; International Organization for Standardization: Geneva, Switzerland, 2006.

29. ISO 21931-1. Sustainability in Building Construction Framework for Methods of Assessment of the Environmental Performance of Construction Works Part 1: Buildings; International Organization for Standardization: Geneva, Switzerland, 2010.

30. Heeren, N.; Hellweg, S. Tracking Construction Material over Space and Time: Prospective and Geo-referenced Modeling of Building Stocks and Construction Material Flows. J. Ind. Ecol. 2019, 23, 253-267. [CrossRef]

31. Tingley, D.D.; Arbabi, H. The importance of understanding the material metabolism of the built environment. In Proceedings of the World Sustainable Built Environment Conference 2017, Hong Kong, China, 5-7 June 2017; pp. 888-894.

32. Pomponi, F.; Moncaster, A. Circular Economy Research in the Built Environment: A Theoretical Contribution. In International Conference on Sustainable Ecological Engineering Design for Society; Leeds Beckett University: Leeds, UK, 2016.

33. De Wolf, C. Low Carbon Pathways for Structural Design: Embodied Life Cycle Impacts of Building Structures. Ph.D. Thesis, Massachusetts Institute of Technology, Cambridge, MA, USA, 2017. 
34. Malmqvist, T.; Nehasilova, M.; Moncaster, A.; Birgisdottir, H.; Nygaard, F. Design and construction strategies for reducing embodied impacts from buildings-Case study analysis. Energy Build. 2018, 166, 35-47. [CrossRef]

35. De Koeijer, B.; Wever, R.; Henseler, J. Realizing Product-Packaging Combinations in Circular Systems: Shaping the Research Agenda. Packag. Technol. Sci. 2017, 30, 443-460. [CrossRef]

36. Hellweg, S.; Mila i Canals, L. Emerging approaches, challenges and opportunities in life cycle assessment. Science 2014, 344, 1109-1113. [CrossRef] [PubMed]

37. Marsh, R. LCA profiles for building components: Strategies for the early design process. Build. Res. Inf. 2016, 44, 358-375. [CrossRef]

38. Meex, E.; Hollberg, A.; Knapen, E.; Hildebrand, L.; Verbeeck, G. Requirements for applying LCA-based environmental impact assessment tools in the early stages of building design. Build. Environ. 2018, 133, 228-236. [CrossRef]

39. Anand, C.K.; Amor, B. Recent developments, future challenges and new research directions in LCA of buildings: A critical review. Renew. Sustain. Energy Rev. 2017, 67, 408-416. [CrossRef]

40. De Wolf, C.; Pomponi, F.; Moncaster, A. Measuring embodied carbon dioxide equivalent of buildings: A review and critique of current industry practice. Energy Build. 2017, 140, 68-80. [CrossRef]

41. Andersen, C.E.; Kanafani, K.; Zimmermann, R.K.; Rasmussen, F.N.; Birgisdóttir, H. Comparison of GHG emissions from circular and conventional building components. Build. Cities 2020, 1, 379. [CrossRef]

42. Birgisdottir, H.; Kanafani, K.; Zimmermann, R.K.; Andersen, C.M.E.; Hatic, D.; Elmbæk, M.; Kamper, M.; Falbe-Hansen, M.; Sack-Nielsen, T. Dialogværktøj: Cirkulær Værdiskabelse i den Eksisterende Bygningsmasse (Dialog Tool: Circular Value Creation in the Existing Building Mass); Aalborg University: Copenhagen, Denmark, 2019.

43. Birgisdottir, H.; Houlihan-Wiberg, A.; Malmqvist, T.; Moncaster, A.; Rasmussen, F.N. IEA EBC ANNEX 57-Subtask 4: Case Studies and Recommendations for the Reduction of Embodied Energy and Embodied Greenhouse Gas Emissions from Buildings; Institute for Building Environment and Energy Conservation: Tokyo, Japan, 2016; ISBN 978-4-909107-08-4.

44. Hollberg, A.; Lützkendorf, T.; Habert, G. Using a budget approach for decision-support in the design process. IOP Conf. Ser. Earth Environ. Sci. 2019, 323, 012026. [CrossRef]

45. Kanafani, K.; Zimmermann, R.K.; Birgisdottir, H.; Rasmussen, F.N. LCA i Tidlig Bygningsdesign: Introduktion til Metoden og Eksempler på Miljøprofiler (LCA in Early Building Design: Introduction to the Method and Examples of Environmental Profiles); Aalborg University: Copenhagen, Denmark, 2019.

46. Eberhardt, L.C.M.; van Stijn, A.; Nygaard Rasmussen, F.; Birkved, M.; Birgisdottir, H. Development of a life cycle assessment allocation approach for circular economy in the built environment. Sustainability 2020, 12, 9579. [CrossRef]

47. Van Stijn, A.; Eberhardt, L.C.M.; Wouterszoon Jansen, B.; Meijer, A. Design guidelines for circular building components based on LCA and MFA. J. Clean. Prod. 2020. submitted.

48. Van Stijn, A.; Eberhardt, L.C.M.; Wouterszoon Jansen, B.; Meijer, A. A Circular Economy Life Cycle Assessment (CE-LCA) model for Buildings and Building Components. Resour. Conserv. Recycl. 2020. submitted.

49. Van Stijn, A.; Gruis, V. Towards a circular built environment: An integral design tool for circular building components. Smart Sustain. Built Environ. 2019. [CrossRef]

50. Eberhardt, L.C.M.; Rønholt, J.; Birgisdottir, H.; Birkved, M. Circular Economy potential within the building stock-mapping the embodied greenhouse gas emissions of four Danish examples. Build. Eng. 2020, 33, 101845. [CrossRef]

51. Rønholt, J.; Eberhardt, L.C.M.; Birkved, M.; Birgisdottir, H.; Niki, B. Tracing the environmental impact origin within the existing building portfolio of prevailing building typologies. In Proceedings of the Submitted to 1st Nordic Conference on Zero Emission and Plus Energy Buildings, Trondheim, Norway, 6-7 November 2019; p. 012065.

52. Partners Circle House. Circle House; KLS PurePrint: Hvidovre, Denmark, 2018; ISBN 978-87-998670-7-3.

53. Van Stijn, A.; Gruis, V.H. Circular Housing Retrofit Strategies and Solutions: Towards Modular, Mass-Customised and "Cyclable" Retrofit Products. IOP Conf. Ser. Earth Environ. Sci. 2019, 290, 012035. [CrossRef]

54. Lignatur, LIGNATUR Element. Available online: https://www.lignatur.ch/en/product/lignatur-element (accessed on 15 October 2020).

55. Copenhagen Cleantech Cluster. CLEAN Report: Kortlægning af Genbrugsmarkeder for Byggematerialer [Mapping of Recycling Markets for Building Materials]; Copenhagen Cleantech Cluster: Copenhagen, Denmark, 2014.

56. Jensen, N.J.J. Beregningssoftware Giver $\mathrm{CO}_{2}$-Besparelser [Calculation Software Results in $\mathrm{CO}_{2}$ Savings]. Available online: http:/ / www.dagensbyggeri.dk/artikel/93549-beregningssoftware-giver-co2-besparelser (accessed on 12 May 2021).

57. Eberhardt, L.; Birgisdottir, H.; Birkved, M. Comparing life cycle assessment modelling of linear vs. circular building components. IOP Conf. Ser. Earth Environ. Sci. 2020, 225, 012039. [CrossRef]

58. Sanchez, B.; Haas, C. A novel selective disassembly sequence planning method for adaptive reuse of buildings. J. Clean. Prod. 2018, 183, 998-1010. [CrossRef]

59. Kohler, N. From the design of green buildings to resilience management of building stocks. Build. Res. Inf. 2017. [CrossRef]

60. Sanchez, B.; Haas, C. Capital project planning for a circular economy. Constr. Manag. Econ. 2018, 36, 303-312. [CrossRef]

61. Aagaard, N.-J.; Brandt, E.; Aggerholm, S.; Haugbølle, K. Levetider af Bygningsdele ved Vurdering af Bæredygtighed og Totaløkonomi; Aalborg University: Copenhagen, Denmark, 2013.

62. Habraken, N.J. Supports: An Alternative to Mass Housing; Urban International Press: London, UK, 1972.

63. Brand, S. How Buildings Learn: What Happens after They're Built; Viking Press: New York, NY, USA, 1994. 
64. Ecoinvent Ecoinvent 3.4-Ecoinvent. Available online: https://www.ecoinvent.org/database/older-versions/ecoinvent-34 / ecoinvent-34.html (accessed on 4 September 2020).

65. Hauschild, M.; Rosenbaum, R.K.; Olsen, S.I. Life Cycle Assessment-Theory and Practice; Springer International Publishing: Cham, Switzerland, 2018; ISBN 9783319564746.

66. Ecochain Environmental Cost Indicator (ECI)—Overview. Available online: https: / / ecochain.com/knowledge/environmentalcost-indicator-eci/ (accessed on 16 October 2020).

67. Vogtländer, J.G.; Baetens, B.; Bijma, A.; Brandjes, E.; Lindeijer, E.; Sergers, M.; Witte, F. LCA-Based Assessment of Sustainability: The Eco-Costs/Value Ratio EVR; Delft University of Technology: Delft, The Netherlands, 2010; ISBN 1090312059.

68. Dahlsrud, A. How corporate social responsibility is defined: An analysis of 37 definitions. Corp. Soc. Responsib. Environ. Manag. 2008, 15, 1-13. [CrossRef]

69. Haney, W.; Russel, M.; Gulek, C.; Fierros, E. Drawing on Education: Using Student Drawings to Promote Middle School Improvement. Sch. Middle 1998, 7, 38-43.

70. Chau, C.K.; Xu, J.M.; Leung, T.M.; Ng, W.Y. Evaluation of the impacts of end-of-life management strategies for deconstruction of a high-rise concrete framed office building. Appl. Energy 2017, 185, 1595-1603. [CrossRef]

71. Diyamandoglu, V.; Fortuna, L.M. Deconstruction of wood-framed houses: Material recovery and environmental impact. Resour. Conserv. Recycl. 2015, 100, 21-30. [CrossRef]

72. Nuñez-Cacho, P.; Górecki, J.; Molina-Moreno, V.; Corpas-Iglesias, F.A. What gets measured, gets done: Development of a Circular Economy measurement scale for building industry. Sustainability 2018, 10, 2340. [CrossRef] 